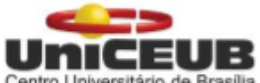

CENTRO UNIVERSITÁRIO DE BRASÍLIA - UnICEUB FACULDADE DE TECNOLOGIA E CIÊNCIAS SOCIAIS APLICADAS

PROGRAMA DE INICIAÇÃO CIENTÍFICA
\end{abstract}

JOÃO ALEXANDRE OTTONI DE CARVALHO

GABRIEL LIMA JACINTO

MOBSBJR: UM JOGO INFANTO-JUVENIL PARA EXPLICAR A MOBILIDADE URBANA EM BRASÍLIA

BRASÍLIA-DF 


\section{UNCEB \\ JOÃO ALEXANDRE OTTONI DE CARVALHO \\ GABRIEL LIMA JACINTO}

MOBSBJR: UM JOGO INFANTO-JUVENIL PARA EXPLICAR A

MOBILIDADE URBANA EM BRASÍLIA

Relatório final do Programa de Iniciação

Científica apresentado à Assessoria de

Graduação e Pesquisa pela Faculdade de Tecnologia e Ciências Sociais Aplicadas FATECS.

Orientação: Prof. a Dra. Ana Paula Borba

Gonçalves Barros

\section{BRASÍLIA-DF}




\title{
MOBsbJr: Um jogo infanto-juvenil para explicar a mobilidade urbana em Brasília
}

\author{
João Alexandre Ottoni de Carvalho - UniCEUB, PICJr Institucional, \\ joao.alexandre@sempreceub.com \\ $\begin{array}{lllll}\text { Gabriel Lima Jacinto - } & \text { Sërios, PICJr } & \text { Institucional, } \\ \text { gabriel.jacinto@colegioserios.com.br } & & & \end{array}$
}

Ana Paula Borba Gonçalves Barros - UniCEUB, professora orientadora ana.barros@uniceub.br

\section{Resumo}

A partir dos problemas de trânsito enfrentados diariamente em cidades brasileiras, inclusive em Brasília, verifica-se a necessidade urgente de uma mudança de paradigma. $E$ sabe-se que tais mudanças apresentam maior probabilidade de eficácia quando iniciadas antes da fase adulta. A partir disto, eis que surgiu a ideia da criação de um jogo de tabuleiro para explicar a mobilidade da cidade para o público infanto-juvenil, de modo a torná-los mais críticos no que tange a relação entre os meios de transporte e os aspectos socioeconômicos dos seus residentes. Sob este viés, a pesquisa visou verificar de que modo os jovens assimilam as informações lúdicas, contidas nos jogos, e as reproduzem. Para tanto, escolheu-se uma instituição de ensino médio parceira (Colégio Sërios) da instituição de ensino superior (UniCEUB) na qual esta pesquisa está vinculada. As etapas metodológicas que amparou o estudo qualitativo, foram as seguintes: na primeira etapa (Grupo Focal), o moderador guiou um grupo de 6 alunos da instituição parceira a construírem um debate coletivo por cerca de 1 hora, com o objetivo de estudar e entender as visões dos participantes; na segunda, ao invés de se preparar desenhos dos elementos físicos presente na cidade (como proposto inicialmente), preferiu-se apenas escolher os elementos mais significativos na cidade de Brasília para os participantes, uma vez que houve atraso na liberação da pesquisa por parte do Comitê de Ética, haja vista trabalhar-se com menores; na terceira (Criação das regras do Jogo) e quarta etapas (Preparação do tabuleiro e das peças), verificouse que os jovens foram bastante cooperativos e flexíveis na elaboração das regras e na exposição de suas ideias; e, na quinta, a primeira partida jogada entre os seus criadores, observou-se a necessidade de alguns ajustes em relação às regras criadas. Portanto, ao longo das etapas, verificou-se um alto nível de visão crítica no que se refere as questões de mobilidade urbana por parte dos participantes, tornando mais simples a comunicação e o entendimento dos assuntos abordados. Houve certa insatisfação com a forma que ocorre 0 trânsito, pois segundo os participantes, em muitos casos não há consciência na escolha do meio de transporte por parte dos usuários da cidade, o que fomentou o enfoque em estratégias de transmitir uma visão crítica através do jogo. Concluise, portanto, que as estratégias lúdicas contidas em jogos contribuem para uma maior interação do jovem com o conteúdo ali expresso, sendo possível estimular, por meio deste tipo de artefato, uma visão mais consciente da utilização dos meios de transporte e sua relação com os aspectos socioeconômicos, bem como 
com os efeitos que causam no ecossistema da cidade. No entanto, cabe ressaltar que a aplicação desta pesquisa deve ser realizada em escolas com níveis de renda mais baixos, pois acredita-se que o objetivo será melhor alcançado. Por fim, salienta-se que este tipo de estratégia leva em consideração a evolução do ensino, a rapidez de aprendizagem, ademais, estimula o foco da atenção dos jovens para o conteúdo ministrado, evitando dispersões verificado com certa frequência nos tempos de hoje.

Palavras-chaves: Mobilidade Urbana. Estratégias Lúdicas. Jogos de Tabuleiro. Público Infanto-Juvenil. Brasília. 


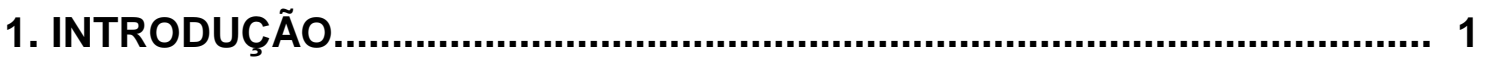

2. FUNDAMENTAÇÃO TEÓRICA.............................................................. 1

2.1. Cidades para pessoas ……......................................................... 1

2.1.1 Jane Jacobs ................................................................ 1

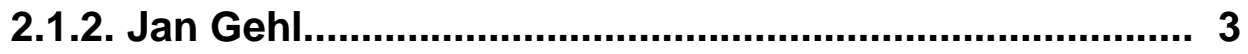

2.2. Placemaking ............................................................................ 3

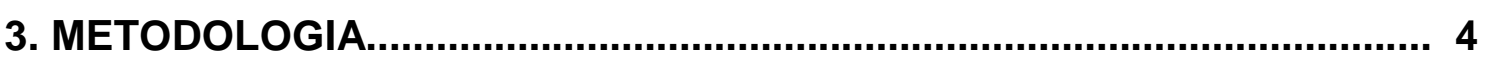

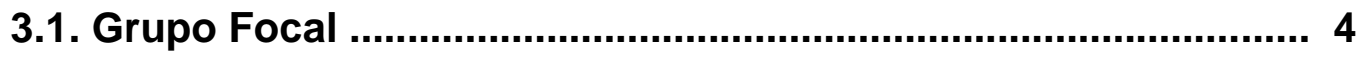

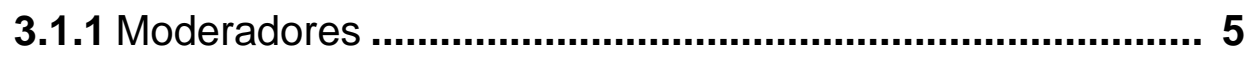

3.1.2 Definição de número de participantes ................................. 6

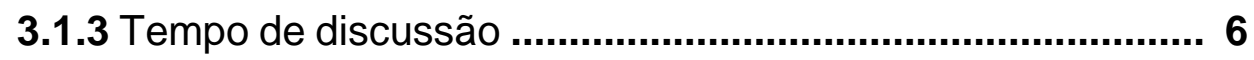

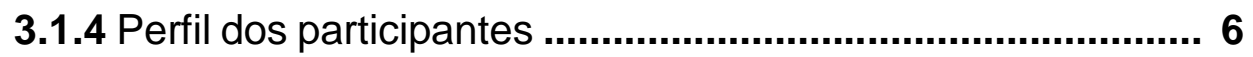

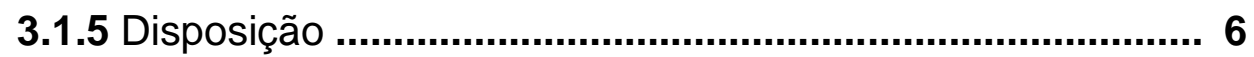

3.2. Preparação dos desenhos ............................................................ 7

3.2.1 Definição das cidades .................................................... 8

3.2.2 Escolha dos pontos de relevância ..................................... 8

3.2.3 Elaboração do mapa ...................................................... 9

3.2.4 Ligação entre os pontos escolhidos ................................. 9

3.3. Criação das regras do jogo ..................................................... 9

3.3.1 Objetivo …................................................................ 10

3.3.2 Elementos de jogo .......................................................... 10

3.3.3 Número de Jogadores .................................................... 10

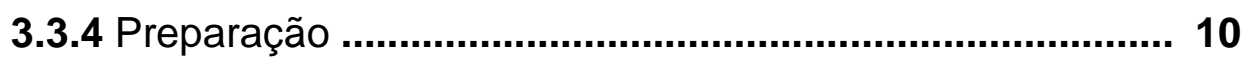

3.3.5 Instruções de jogo ........................................................ 11

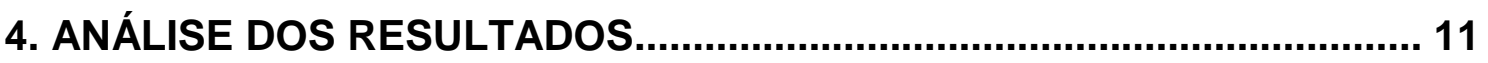

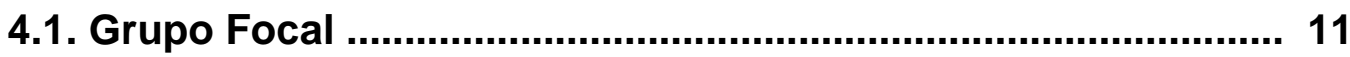

4.2. Preparação dos desenhos ....................................................... 12 


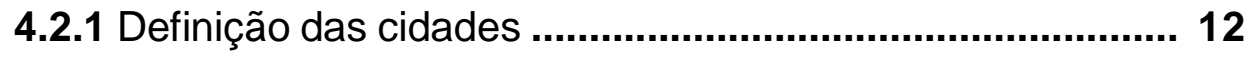

4.2.2 Escolha dos pontos de relevância .................................... 13

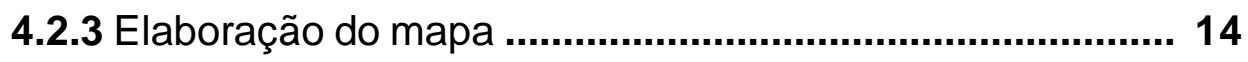

4.2.4 Ligação entre os pontos escolhidos .................................... 15

4.3. Criação das regras do jogo ..................................................... 17

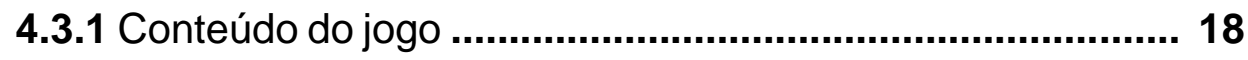

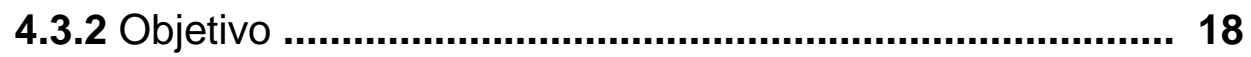

4.3.3 Meios de transporte .......................................................... 18

4.3.4 Preparando o jogo .......................................................... 20

4.3.5 Começa a partida ............................................................ 20

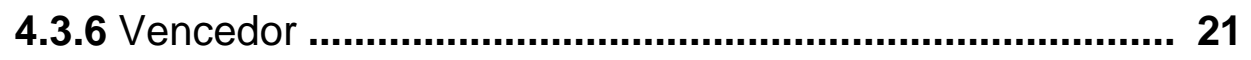

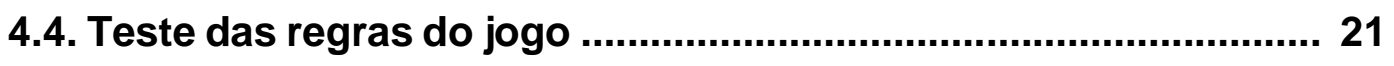

4.4.1 Primeira rodada ............................................................ 21

4.4.2 Segunda rodada ............................................................. 24

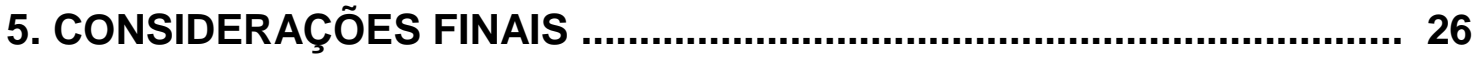

5.1. Conclusões ........................................................................... 26

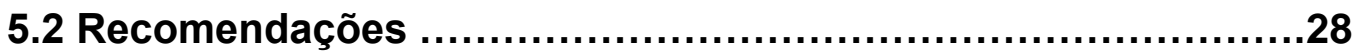

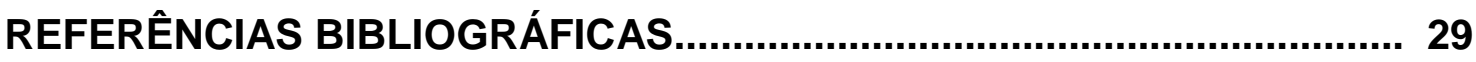

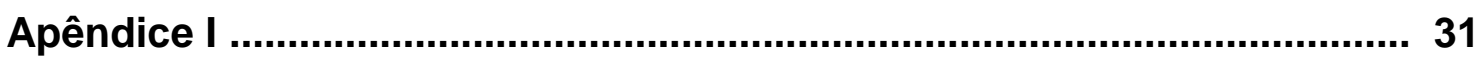

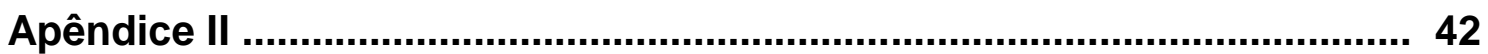




\section{INTRODUÇÃO}

Sabe-se que, no Brasil, o foco das ações de mobilidade urbana é voltado quase que exclusivamente ao trânsito motorizado, não se restringindo às políticas governamentais, mas também às estratégias de Marketing acerca do sonho e status para se obter o primeiro veículo.

Os pais, muitas vezes, sob a influência do sistema midiático que domina o Brasil, fazem com que, desde cedo, seus filhos sejam estimulados a utilizarem, de forma exacerbada, os veículos motorizados. Cabe enfatizar, que as crianças reproduzem aquilo que veem, portanto, o papel dos pais e professores é de extrema relevância no aprendizado das crianças.

Autores como Magnani (1993), Jacobs (2000) e Gehl (2010), acreditam que a rua representa o espaço mais democrático de uma cidade, e, portanto, deve ser utilizado por todos e pensado para todos. Neste viés, Sadik-Khan e Solomonow (2016) e Kent (2005), trabalham com as ações conhecidas como Placemaking (literalmente, fazer/criar espaços), de modo que a sociedade civil possa participar da criação de espaços de convivência.

Neste sentido, a ideia é estimular jovens e crianças a utilizarem os espaços urbanos para entenderem e até participarem do processo criativo, tal como já ocorre na Índia (Bernard van Leer, 2014). Tais ações estimulam as crianças desde muito jovens a se sentirem parte de um sistema, tal como cita Vanderbilt (2009), possibilitando que estas possam ser mais ativas politicamente e como cidadãos.

Portanto, com base nessa crítica à cidade, surge então a questão da pesquisa: Em que medida estratégias lúdicas (como os jogos e as brincadeiras) podem estimular jovens e crianças a absorverem informações?

\section{FUNDAMENTAÇÃO TEÓRICA}

\subsection{Cidades para pessoas}

\subsubsection{Jane Jacobs}

Jacobs (2000) formulou quatro condições que acreditava ser essenciais para que houvesse diversidade "exuberante" em espaços públicos urbanos, o que favorecia seu uso, gerando fluxos e segurança. 
- Diversidade de uso do solo

A autora acreditava que "o total absoluto de pessoas que utilizam as ruas e a maneira como elas se distribuem ao longo do dia são coisas distintas". Pode haver grande movimento em um determinado espaço, em apenas um momento do dia, por exemplo, o que implicaria ociosidade em algumas horas. Um centro comercial que funciona apenas no horário comercial, promove um conjunto de espaços completamente vazios à noite, ou com a presença de usos ocultos. Não é essa a distribuição temporal de atividades que se deseja para uma cidade.

Portanto, para Jacobs (2000) "as misturas dos usos principais devem ser eficientes para gerar a diversidade" ao longo de períodos de tempos mais extensos. $\mathrm{O}$ aspecto evitaria a impressão de áreas mortas, que se tornam onerosas economicamente e socialmente, sem contar os tipos de atividades que ali podem se desenvolver.

- Maior conectividade entre os espaços - quadras curtas

No que diz respeito às relações entre macroparcelas, microparcelas e sistemas de vias, Jacobs (2000) observava as desvantagens existentes no predomínio de quadras longas, uma vez que essa composição acentua o isolamento da vizinhança, tornando os caminhos mais longos.

Portanto, como afirma a autora, uma maior quantidade de vias e a existência de "quadras curtas são valiosas por proporcionar uma rede de usos combinados e complexos entre os usuários do bairro" o que fomenta a vivacidade do espaço, tornando-o mais seguro e convidativo.

- Idades variadas dos edifícios

Sobre a idade dos edifícios, Jacobs (2000) declara que talvez seja impossível existirem ruas vivas sem a presença de prédios antigos. Para a autora, não seria a idade de um ou alguns edifícios que provocaria o fracasso de um espaço, mas sim o seu insucesso a causa do abandono e velhice da área.

- Densidade urbana significativa

Jacobs (2000) menciona que já em 1785 Samuel Jonhson relacionava a concentração de pessoas às especialidades que elas conseguem manter. Ou seja, a concentração 
de pessoas gera as centralidades urbanas e, por conseguinte, as diversidades dela inertes.

Através dessas condições, é possível estudar como a linha do metrô interfere no deslocamento a pé em Águas Claras, e conseguir prever possíveis passarelas para pedestres.

\subsubsection{Jan Gehl}

Gehl (2010) acredita que as atividades se dividem em três tipos: (a) necessárias, (b) opcionais e (c) sociais. A relação entre tais tipos de atividade e a qualidade do ambiente físico externo ocorre de três maneiras: (a) para que as atividades necessárias sejam realizadas, a qualidade do ambiente externo é irrelevante; (b) para que aconteçam as atividades opcionais, a qualidade do ambiente externo é determinante e, por fim, (c) para as atividades sociais, a qualidade do ambiente físico interfere no seu acontecimento, no entanto, numa escala inferior às opcionais (a depender do que motive as atividades sociais, as condições são desprezadas).

Em relação às primeiras (necessárias), estão relacionadas com as atividades de deslocamento casa-trabalho, casa-estudo, etc. Ou seja, aquelas imprescindíveis; quanto às opcionais, associam-se às atividades essencialmente de lazer e de ócio, como a leitura de um livro, brincadeiras com colegas, conversa com amigos, encontros ao ar livre, etc., ou seja, atividades que podem ser realizadas em qualquer altura; e, por fim, em relação às atividades sociais, correspondem aos eventos que tenham hora e data marcada, como exemplo, tem-se os eventos culturais em geral, ou seja, aqueles que não podem ser realizados em outras alturas, mas que não dependem exclusivamente de nós.

\subsection{Placemaking}

Segundo Heemann e Santiago (2015), os conceitos que alimentam o Placemaking surgem na década de 60, quando Jacobs (2000), Whyte (1980), Gehl (2010) e outros divulgaram ideias inovadoras, no qual o desenvolvimento das cidades deveria voltarse às pessoas e não aos carros.

Placemaking é, concomitantemente, um conceito e uma ferramenta para melhorar qualquer escala do espaço público urbano (um bairro, uma cidade ou uma região). Estando suas raízes inseridas na participação comunitária, o Placemaking "abrange o 
planejamento, o desenho, a gestão e a programação de espaços públicos" (Heemann e Santiago, 2015). Para as autoras, o Placemaking, é

"mais do que apenas criar melhores desenhos urbanos para esses espaços, Placemaking facilita a criação de atividades e conexões (culturais, econômicas, sociais, ambientais) que definem um espaço e dão suporte para a sua evolução" (Heemann e Santiago, 2015).

Conforme já mencionado anteriormente, Jacobs (2000) defendia a ideia de que ruas com pessoas são ruas mais seguras, usando o termo "olhos na rua" para explicar que, sem perceber, as pessoas são responsáveis por observar o uso dos espaços e zelar pela sua segurança.

Por outro lado, Whyte (1980) enfatizava os elementos essenciais que um espaço público deve ter para atrair pessoas e se tornar um lugar de convivência e vida, enquanto Gehl (2010) propõe que a arquitetura e urbanismo devem pensar primeiro nas pessoas, depois no espaço e só então nos prédios.

Portanto, Placemaking, pode ser utilizado por diversas camadas da sociedade, e no caso deste estudo, esteve vinculado às escolas de nível médio, de modo a buscar incentivar os jovens pelo interesse em melhorar os espaços da cidade em estudo.

\section{METODOLOGIA}

De modo a atingir os objetivos propostos na presente pesquisa, foi realizado uma compreensão e interpretação de um grupo específico, sendo assim, sem a atribuição de resultados qualitativos (numéricos), porém apresentando relatórios, falas transcritas dos participantes, trechos e opiniões sobre o assunto.

\subsection{Grupo Focal (GF):}

A fim de conseguir realizar os objetivos mesurados, foi criado uma proposta de Grupo Focal, que consiste em uma técnica de discussão em grupo, em que os participantes expõem suas opiniões através de uma pergunta direcionada de um moderador, criando assim âmbitos de discussões de ideias entre os próprios participantes.

Kitzinger (2000), define grupo focal como um modelo de entrevista em grupo, em que se constitui da comunicação e interação, tendo como fim, coletar dados precisos de um tema específico através de um grupo de participantes selecionados. 
Para a efetiva realização da etapa proposta, faz necessário considerar um conjunto de elementos que asseguram o total funcionamento: Moderadores; Definição de número de participantes; Perfil dos participantes; Tempo de discussão.

\subsubsection{Moderadores:}

O moderador é de suma importância para a realização do GF, sendo ele responsável direto pelo desenvolvimento e andamento da discussão do grupo. Salienta-se que é imprescindível que o moderador tenha total conhecimento sobre o tema em questão para que esteja apto a conduzir o grupo. Além do moderador é necessário a presença de um apoio, que atua como um segundo moderador dando assistência ao moderador chave (Trad, 2009).

Scrimshaw e Hurtado (1987) aponta como função do moderador: Introduzir a discussão e a manter acesa; Enfatizar para o grupo que não há respostas certas ou erradas; Observar os participantes, encorajando a palavra de cada um; Buscar as "deixas" de comunidade da própria discussão e fala dos participantes; Construir relações com os informantes para aprofundar, individualmente, respostas e comentários considerados relevantes pelo grupo ou pelo pesquisador; Observar as comunicações não-verbais e o ritmo próprio dos participantes, dentro do tempo previsto para o debate.

Algumas medidas devem ser tomadas para assegurar o desenvolvimento

"O objetivo do grupo deve ser expresso de forma clara no momento de abertura dos trabalhos, sinalizando as questões centrais sobre as quais a discussão irá concentrar-se. Após breve apresentação dos participantes, é conveniente especificar as regras básicas de funcionamento dos grupos, esclarecendo de partida o papel do moderador. Gondim (2002) apresenta uma lista básica de regras para esta ocasião, a saber: 1) falar uma pessoa de cada vez; 2) evitar discussões paralelas para que todos possam participar; 3) dizer livremente o que pensa; 4) evitar o domínio da discussão por parte de um dos integrantes; 5) manter a atenção e o discurso na temática em questão" (Trad, 2009). 
3.1.2 Definição de número de participantes:

O número de participantes pode ser definido de 6 a 15 pessoas, entretanto, um bom tamanho para o GF é o que permite a efetiva participação e a discussão adequada dos temas por todos os envolvidos (Pizzol, 2004).

\subsubsection{Tempo de discussão:}

"O número de participantes no grupo focal incidirá, sem dúvida, na sua duração. A complexidade do tema ou o grau de polêmica em torno das questões que se apresentam são outros fatores que podem interferir neste ponto. Contudo, uma variação entre 90 (tempo mínimo) e 110 minutos (tempo máximo) deve ser considerada para um bom emprego da técnica" (Trad, 2009).

\subsubsection{Perfil dos participantes:}

Segundo Tand (2009), os participantes do GF devem ter características homogêneas no que se refere ao tópico central do estudo, para que não haja discrepância no tocante ao tema.

Para fins de uma maior abrangência e enriquecimento das opiniões, optou-se pela escolha de candidatos com diferentes classes sociais e econômicas, que tenham formas diferentes de contatos com os meios de deslocamento e com a própria cidade, em ambientes distintos e ao mesmo tempo que dispõem de algumas similaridades, para que, assim, haja uma discussão progressiva e concisa.

\subsubsection{Disposição:}

Os integrantes do grupo focal devem ser dispostos de forma que permita a interação de todos, sendo assim deve possibilitar que todos consigam observar o que está acontecendo no momento, como, por exemplo, quem está expondo sua opinião. Para tal, é de costume dispor os integrantes em forma de roda (Figura 1), entretanto, tendo em vista o número de participantes destinado ao projeto, optou-se por um formato que tivesse as mesmas características: o quadrado (Figura 2). 


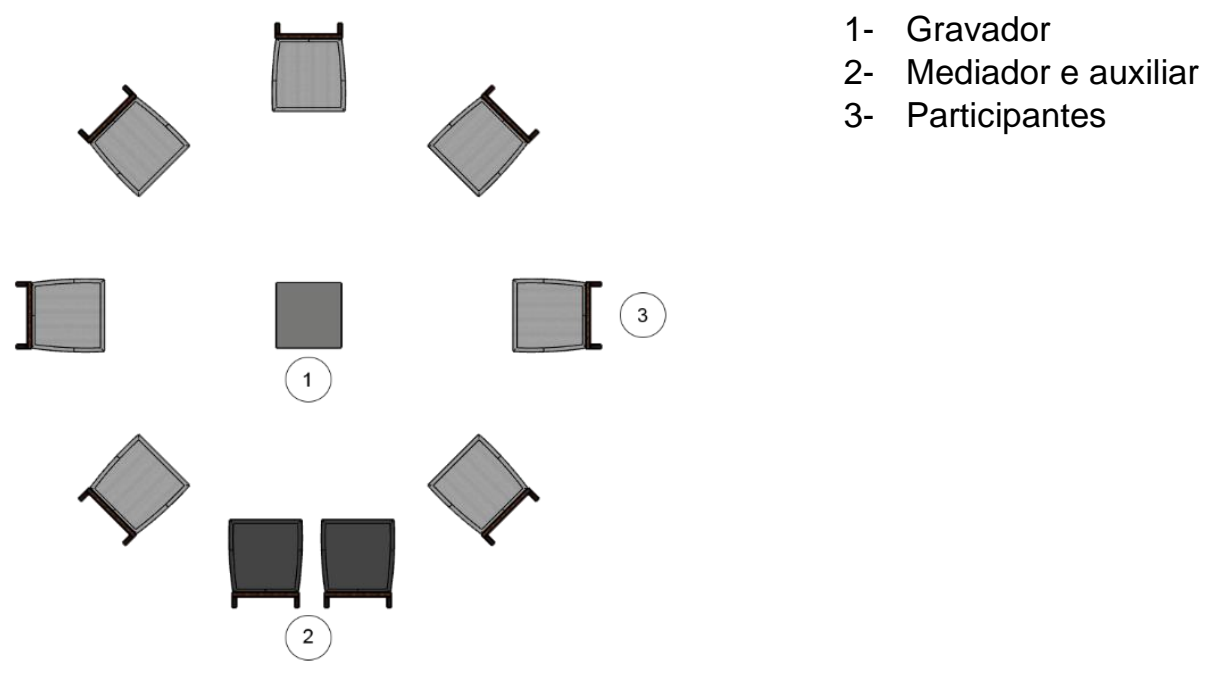

Figura 1: Modelo de um grupo focal cadeira dispostas em roda.

Fonte: Arquivo pessoal.

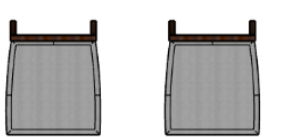

1- Gravador

2- Mediador e auxiliar

3- Participantes
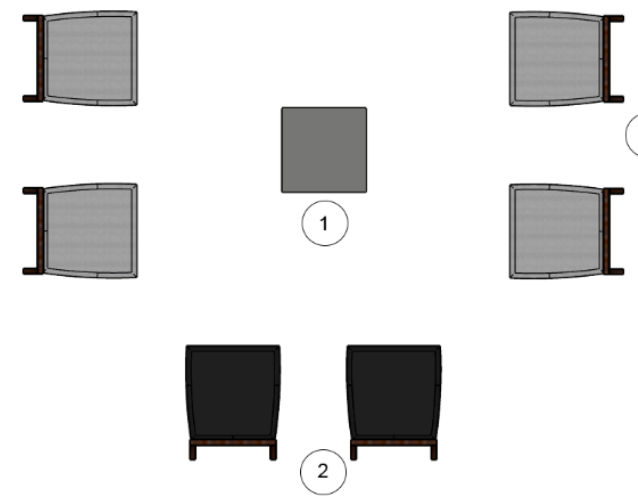

Figura 2: Modelo de um grupo focal cadeira dispostas em quadrado.

Fonte: Arquivo pessoal.

\subsection{Preparação dos desenhos:}

Para Heemann e Santiago (2015), placemaking é muito mais que um simples planejamento, compreende o desenho, a gestão e a programação de espaços públicos, é uma estratégia que utiliza a própria comunidade para criar o lugar, pois o lugar não existe sem a comunidade e a recíproca é verdadeira. 
Dessa forma, é preciso a participação efetiva das pessoas que vivem no local para a criação do espaço, isso se dá através de "olhar, ouvir e fazer perguntas", adquirindo informações que poderão ser utilizadas para a "criação de uma visão compartilhada do espaço", criando, assim, valores em cima dos ativos da comunidade.

Com base nisto, a fim de compreender os signos da cidade que possuem maior relevância para a comunidade que estava sendo observada, usufruiu-se das estratégias expostas no placemaking, tendo total participação do grupo, cabendo aos integrantes do projeto o auxílio e pontual moderação a assuntos específicos. O trabalho de elaboração dos desenhos da cidade dividiu-se em etapas: Definição das Cidades que participariam do jogo; Escolha dos seus pontos de relevância; Elaboração do mapa; Interligação dos pontos das cidades;

\subsubsection{Definição das cidades:}

Essa etapa tem o intuito de observar como os integrantes interagem na idealização de quais áreas possuem mais relevância para a cidade e qual delas devem ser postas no jogo, analisando se as cidades que possuem menos condições de infraestrutura e renda devem ou não constar.

3.2.2 Escolha dos pontos de relevância:

Os pontos de relevância para a cidade são definidos como pontos de interesses, que geram tráfego e se tornam marcos para a própria identificação da cidade. Fazendo um paralelo as ideias de Pierce (2010), esses marcos tornam-se signos da cidade, mais precisamente "símbolos", pois cria-se uma relação puramente convencional entre o significado (marco da cidade) e o significante (a própria cidade), assim como a Torre Eiffel representa Paris, Cristo Redentor ou o Pão de Açúcar representam o Rio de Janeiro. (Figura 3) 


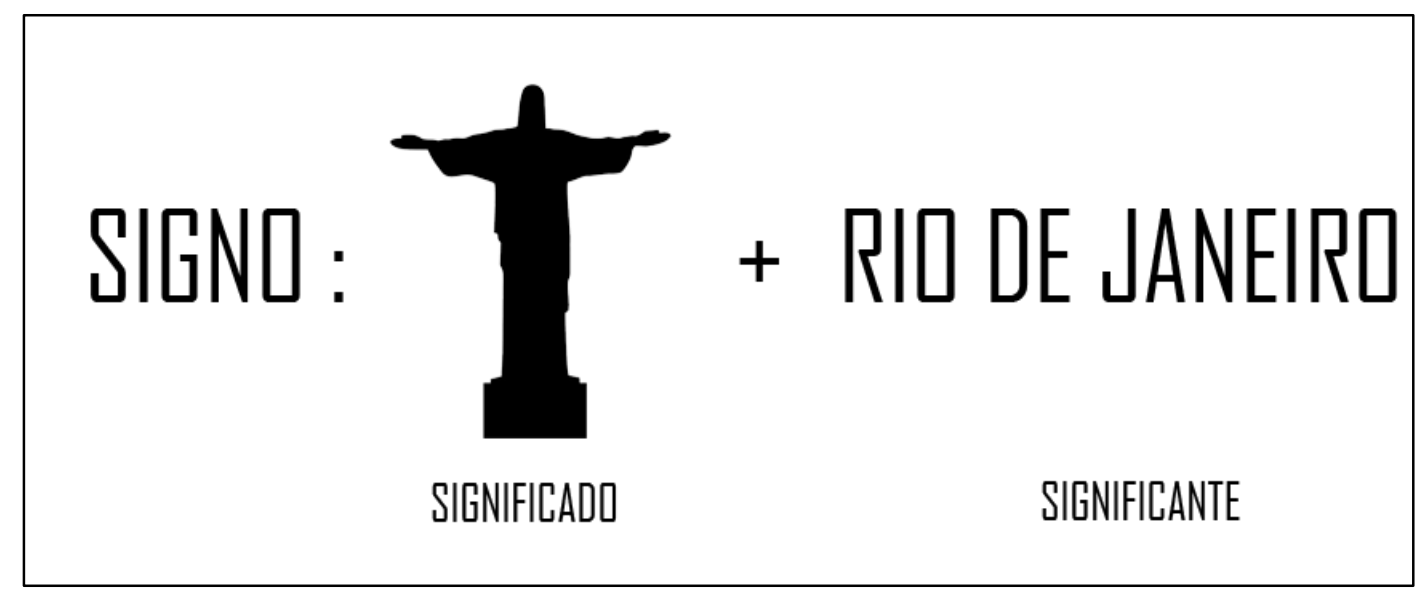

Figura 3: Representação da relação do signo.

Fonte: Arquivo pessoal.

\subsubsection{Elaboração do mapa:}

A partir da análise dos locais escolhidos para serem representados, surge a necessidade de dispor os mesmos no tabuleiro, portanto, essa etapa é um complemento da anterior e serve como meio para a análise das relações entre cada elemento que a constitui.

Por meio da discussão entre o grupo, foi escolhido a forma que melhor representa o DF, levando em consideração que se tratando de um jogo de tabuleiro e deve ser seguido alguns aspectos, como: um desenho que permita a interação dos jogadores com o jogo, além disso, uma boa identificação, por parte dos jogadores, dos elementos que constituem o tabuleiro.

3.2.4 Ligação entre os pontos escolhidos:

As ligações entre os pontos servem como meio para propiciar uma dinamicidade ao jogo, também representa a forma como ocorrem as relações no trânsito e suas consequências. As conexões representam os encadeamentos das cidades, como, por exemplo, as rodovias e as ciclovias, que podem ser usufruídas pelo cidadão.

\subsection{Criação das regras do jogo:}

As regras são uma parte fundamental na lógica (funcionamento) do jogo, pois servem tanto para direcionar, como delimitar o andamento do jogo, tentando fazer com que 
todos consigam entender e jogar, evitando possíveis confusões por parte de alguns jogadores.

São as regras que proporcionam uma partida igualitária a todos, pois definem o que é certo e errado perante o jogo, estruturando e definindo uma coerência.

Nas regras devem constar alguns elementos que dão forma à partida, tais como: Objetivo; Elementos de jogo; Número de Jogadores; Preparação; Instruções de jogo;

\subsubsection{Objetivo:}

Todo jogo há um objetivo, de modo a mover os participantes a tomarem decisões perante o que ocorre durante a partida, sendo este o que todos os jogadores pretendem alcançar, ou seja, este é o propósito do jogo.

\subsubsection{Elementos de jogo:}

Os elementos são partes fundamentais do jogo, pois criam e moldam a partida. No caso deste jogo, os elementos vão desde o pino, o mapa, até elementos específicos como algum local ou edificação própria.

São os componentes do jogo que dão ao jogador uma vivência do mesmo, tornandoo tangível e concreto.

\subsubsection{Número de Jogadores:}

Os integrantes são os membros que participam do jogo, constitui um grupo delimitado de pessoas para que haja uma melhor jogabilidade, podendo envolver duas ou mais pessoas entre si, como adversários ou cooperativamente, como grupos de adversários que interagem entre si.

A intenção primária era que o jogo incentivasse a cooperatividade total por partes dos jogadores, entretanto, após testes foi observado que o elemento de competitividade é de extrema importância para criar a interação neste tipo de jogo. Essa interação é essencial para o decorrer do jogo, propiciando a existência de um vencedor e um perdedor.

\subsubsection{Preparação:}

A preparação é uma etapa tida como "pré-jogo", pois antecede o jogo propriamente dito. Nessa etapa é quando se arruma o tabuleiro com os elementos disponíveis de 
acordo com os participantes, em alguns casos, nessa etapa há a realização de algumas ações que podem influenciar ou influenciam o andamento do jogo, como por exemplo a escolha de algum utensilio do jogo ou a puxada ${ }^{1}$ de cartas do baralho.

\subsubsection{Instruções de jogo:}

As instruções do jogo é um manual, como uma receita que deve ser lida antes do preparo do prato para que possa sair como planejado, assim como uma receita há a possibilidade de ter alterações de acordo com as escolhas de quem usufrui das instruções, mas a ideia do manual de instruções é dá aos participantes as direções necessárias para que possam usufruis do jogo.

Nesse manual há elementos importantes como a condição de vitória, em alguns casos a condição de derreta que desclassifique o participante, o papel de cada integrante do jogo, como deve ocorrer a movimentação, como se utiliza o mapa e suas peças entre outras informações que o fabricante julgue necessário para a realização do jogo.

\section{ANÁLISE DOS RESULTADOS}

\subsection{Grupo Focal:}

Com o intuito de preservar a privacidade dos participantes, foi entregue aos participantes placas com nomes de cidades europeias (Roma, Paris, Barcelona, Berlim, Amsterdam, Londres, Moscou), para que não fosse usado seus nomes pessoais durante todo o processo.

A nuvem de palavras é um instrumento gráfico que permite observar a frequência dos termos que mais foram expressos durante um texto, dessa forma, houve uma transcrição dos áudios dos grupos focais para que houvesse um estudo.

Observou-se que as palavras mais utilizadas fazem referencia ao ser humano, como "Você" (83 vezes) e "Gente" (48 vezes), mostrando algo que Gehl (GEHL, 2010) e Jacobs (Jacobs, 2000) já demonstram em seus estudos: que quando se refere a cidade, as relações com a mesma se tornam mais interessante para o ser humano, quando é observado as necessidades e vontade do próprio ser humano (Figura 4).

\footnotetext{
1 Puxada, nesse caso, é um movimento que um dos participantes faz em posse do baralho, retirando uma ou mais cartas, de acordo com as instruções.
} 


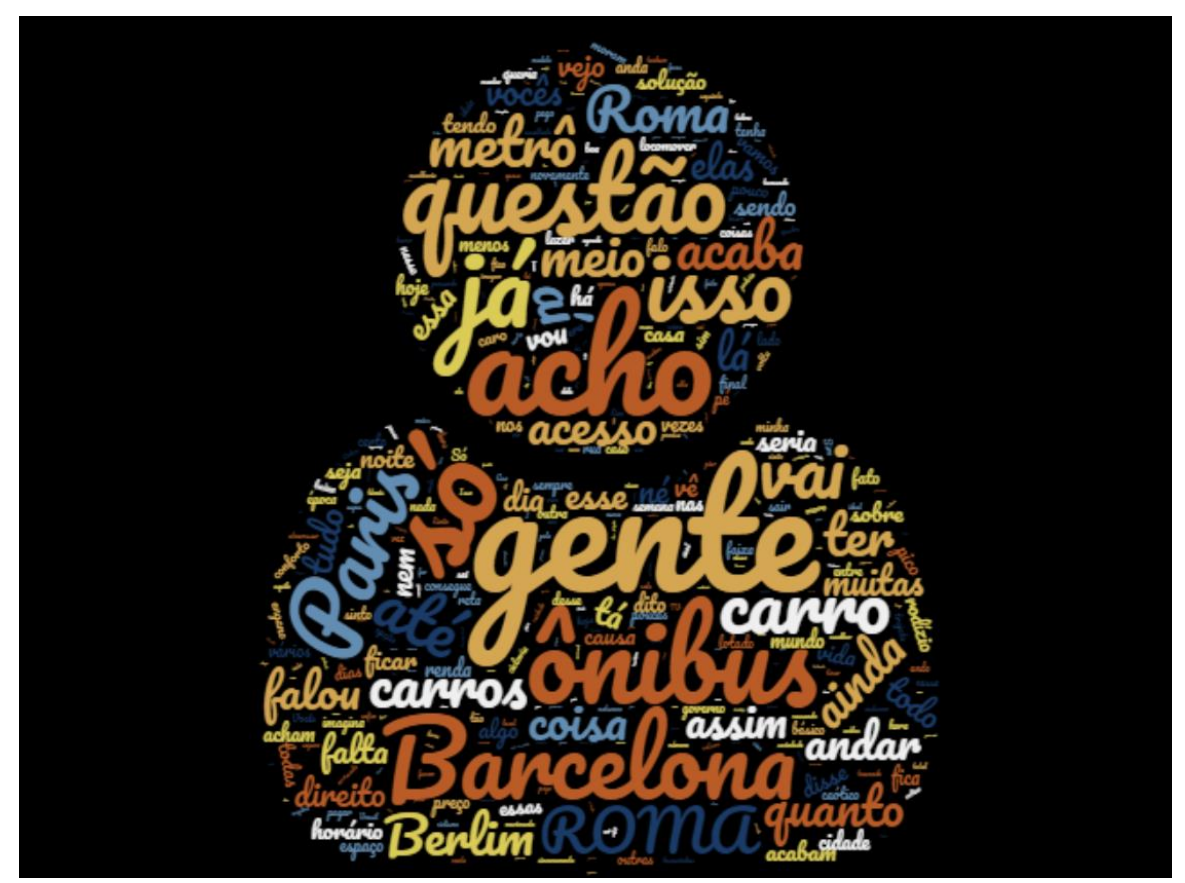

Figura 4: Nuvem de palavras do Grupo Focal.

Fonte: Elaboração própria.

Em segundo plano ao analisar a nuvem de palavras tornasse notório palavras referentes aos meios de transporte, como "Ônibus" (37 vezes), "Carro" (23 vezes), "Trânsito" (23 vezes), "Metrô" (21 vezes), "Carros" (19 vezes). Mostrando assim, o poder que possui o meio de transporta para a mobilidade da cidade $\mathrm{e}$ consequentemente para que ocorra a vida na cidade (Jacobs, 2000).

\subsection{Preparação dos desenhos:}

4.2.1 Definição das cidades:

As primeiras discussões sobre o ponto levantado em questão geraram um questionamento perante o próprio grupo: "Por que colocar apenas algumas cidades tidas como mais relevantes? Por que não propiciar maior inclusão das pessoas colocando todas as cidades?"

Esses questionamentos levaram a uma pesquisa de todas as RA's (Regiões Administrativas) presente no Distrito Federal e a inserção de todas no tabuleiro do jogo (Figura 5), para que não gerar, por partes dos jogadores, nenhum sentimento de revolta ou inferioridade por não ver determinada região no tabuleiro. 


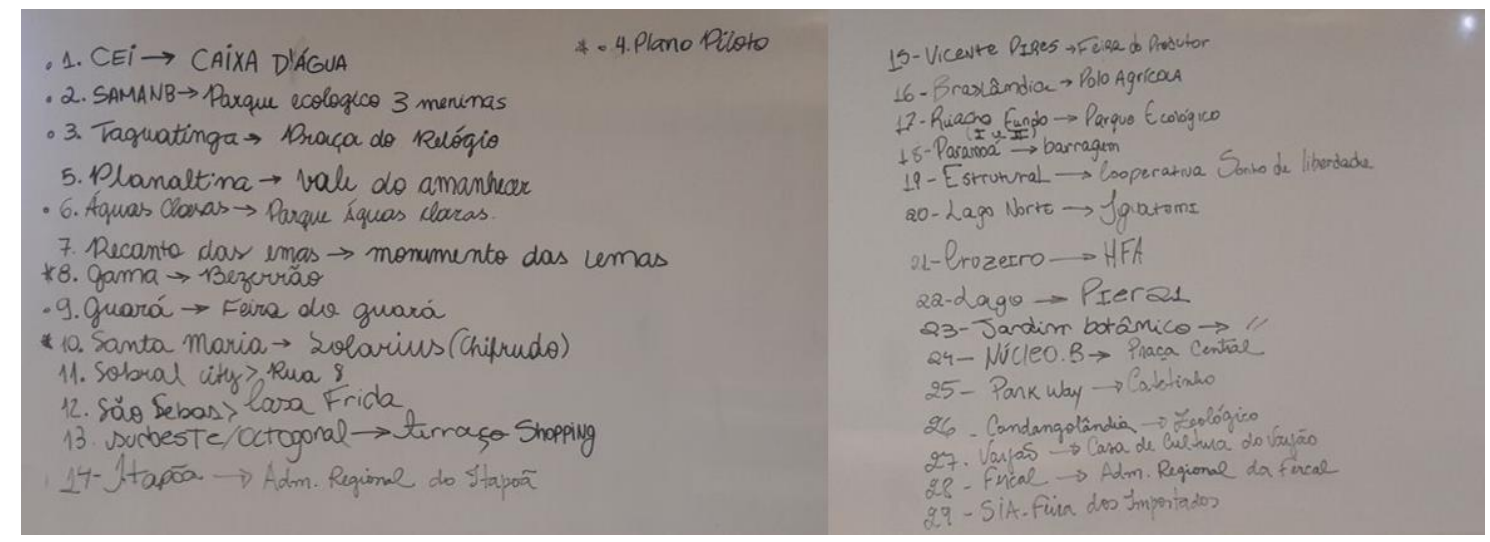

Figura 5: Foto tirada da lista feita pelos estudantes com todas as RA's que deviam estar presentes no jogo e seus pontos de interesses.

Fonte: Elaboração própria.

Essa medida proporciona uma maior conexão e integração das pessoas com o jogo, principalmente as que residem em locais mais carentes, através da visualização do seu local de moradia (Seu lar) presente em tal objeto, dado que muitas das vezes há uma exclusão das áreas mais carentes e desfavorecidas, o que normalmente gera incômodo e até revolta.

A demonstração de uma visão mais social e que proporciona uma maior inclusão das pessoas, foi, notoriamente, observado perante todos os integrantes do grupo e apesar de ocorrer alguns posicionamentos contrários à algumas ideias, sempre houve o consenso de optar pelo o que a maioria escolhesse como sendo o melhor para a finalidade do jogo, sempre levando em consideração como isso afetaria quem fosse jogar, possuindo assim, uma visão mais humanitária e empática perante o próximo.

4.2.2 Escolha dos pontos de relevância:

Com a definição da lista das regiões administrativas que deveriam constar no trabalho realizou-se uma nova pesquisa por cidade, verificando os marcos que têm grande importância para a comunidade, através de monumentos históricos da cidade, locais de grande fluxo de pessoas e/ou que sejam conhecidos da população, ou seja, algo que caracterize o local.

Ao fazer a pesquisa, os alunos optaram, novamente, pela padronização do número de pontos de interesses para não gerar conflitos perante os futuros jogadores. Desta forma, escolheram definir um marco para cada cidade conforme pode ser observado 
na figura 5. Entretanto, devido a limitação referente ao espaço no tabuleiro, optou-se por inserir apenas os nomes das RA's.

\subsubsection{Elaboração do mapa:}

Baseado nas listas das RA's e dos pontos de interesses, surgiu a necessidade da sua disposição no mapa, através disso e de outros elementos já citados ${ }^{2}$ que devem ser levados em consideração para a elaboração de um bom tabuleiro, a partir disso o grupo se viu frente à duas formas de abordar o desenho do mapa no tabuleiro: a representação idêntica do mapa cartográfico real (muitas vezes realizada por escala) ou uma representação diagramática.

Devido ao fato de se tratar de um jogo e não haver a necessidade de uma representação real, tal qual é, por meio de escala e, além disso, o tamanho que ocuparia esse tipo de representação para poder ter uma nítida identificação, optou-se por uma representação simbólica que possa remeter às características do limite espacial da RA (Figura 6), assim como um diagrama que representa uma ideia.

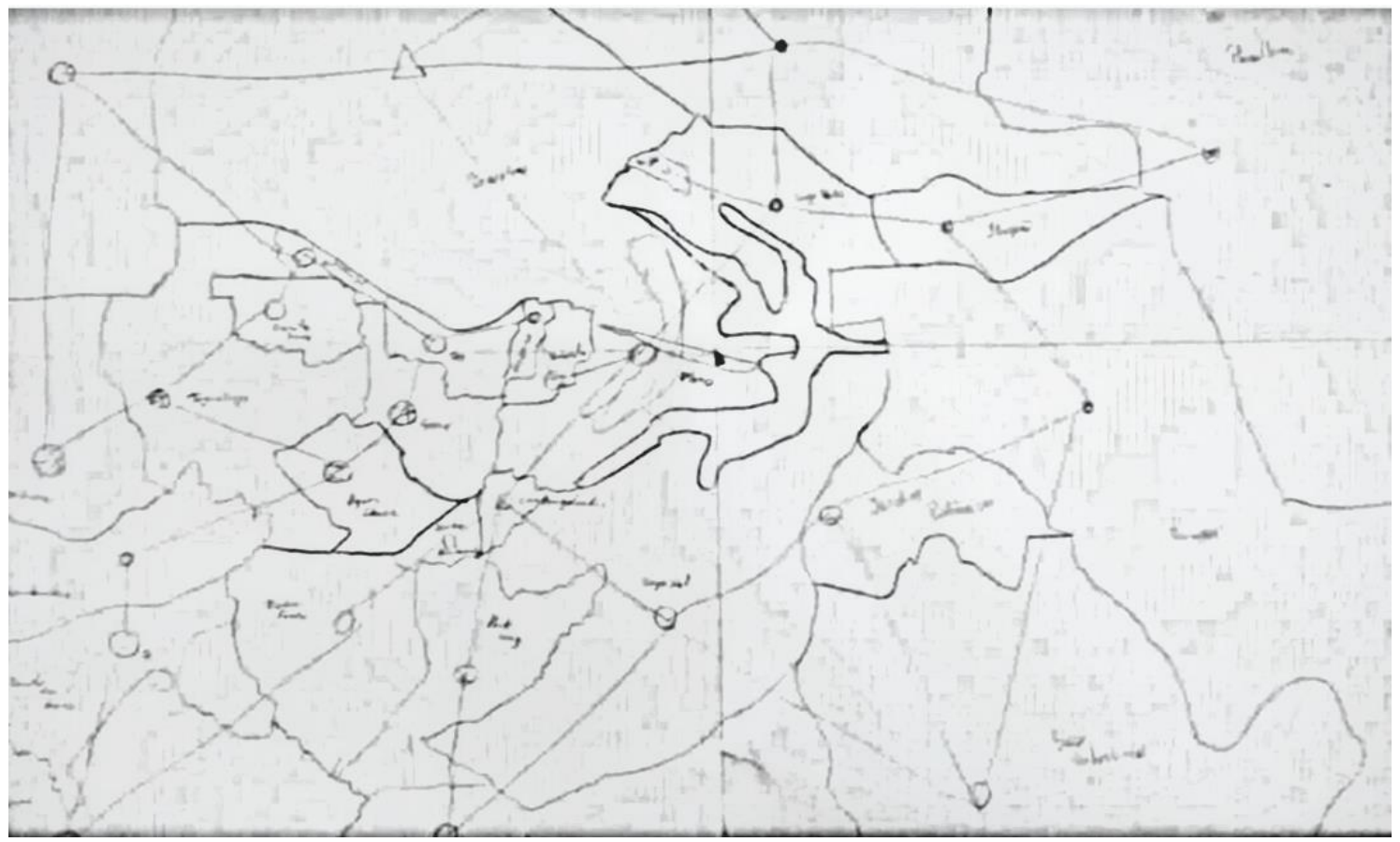

Figura 6: Foto tirada do esboço do tabuleiro realizado pelos estudantes.

Fonte: Elaboração própria.

\footnotetext{
${ }^{2}$ Esses elementos foram citados na parte referente a metodologia "elementos do mapa".
} 
Após escolherem o tipo de representação, o grupo começou a desenvolver ideias para a caracterização dos territórios, observando principalmente o formato que eles possuem para tentar sintetizar de modo a manter sua forma (Figura 7 ).

Dessa forma, ao finalizar esse estudo das formas, a disposição foi feita de forma a enfatizar o Plano Piloto, pois é o local onde há maior movimento de pessoas e o destino de muitos dos deslocamentos na região (Figura 6).

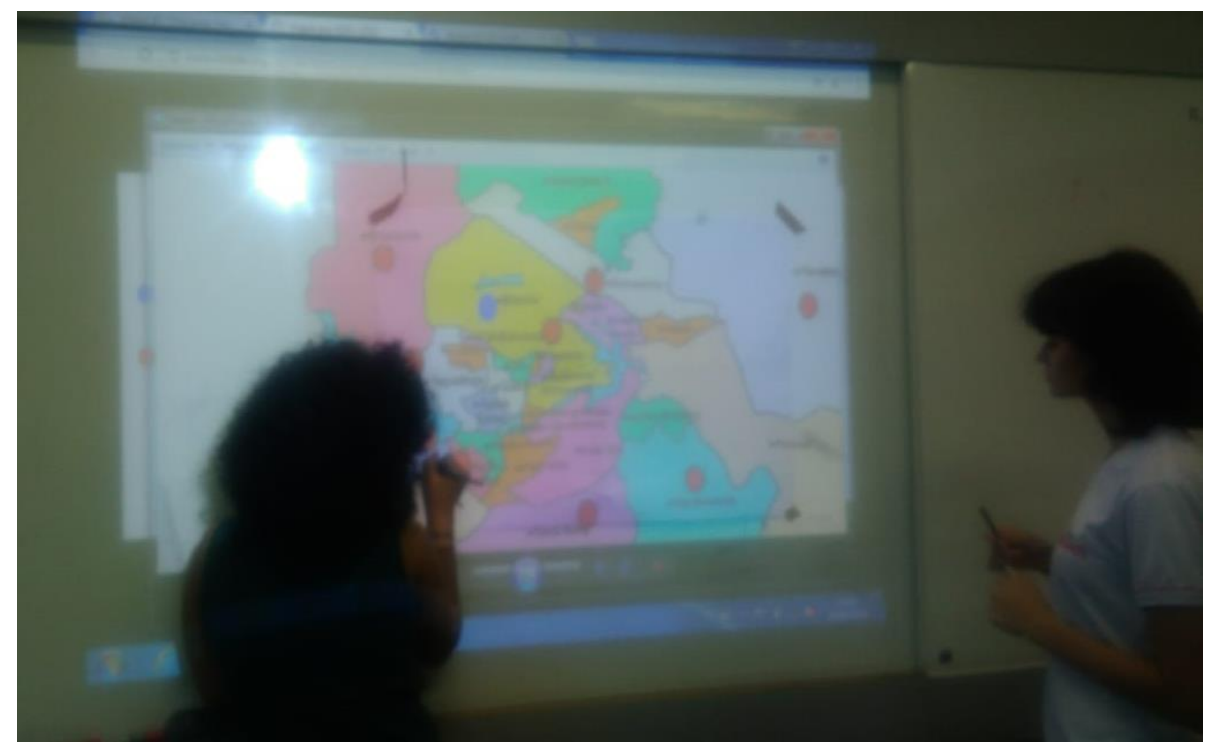

Figura 7: Foto tirada do estudo das formas das RA's.

Fonte: Arquivo pessoal.

\subsubsection{Ligação entre os pontos escolhidos:}

Primeiramente, foi definido quais os tipos de locomoção seriam utilizados, levando em consideração os meios de deslocamento presentes em uma cidade, tais como:

- Deslocamento sem uso de veículo automotor: Deslocamento a pé e por bicicleta.

- Deslocamento por veículo motorizado: Carro, Ônibus e Metrô.

Após refletirem e decidirem que tipo de transporte utilizar, o ponto levantado foi: "Como seriam realizadas as ligações dos pontos e por onde andariam os meios de transporte?"

Para se conseguir escolher como que se dariam as ligações, surgiu entre os alunos duas vertentes: os que optavam por usar como referência as estradas já existentes e 
os que viam como melhor opção fazer uma ligação direta entre os pontos, como um "ligue os pontos"3.

Pensando do ponto de vista de representar melhor a cidade, o grupo decidiu testar a ideia de usar como referência as estradas que existem (Figura 8), como as rodovias e ciclovias.

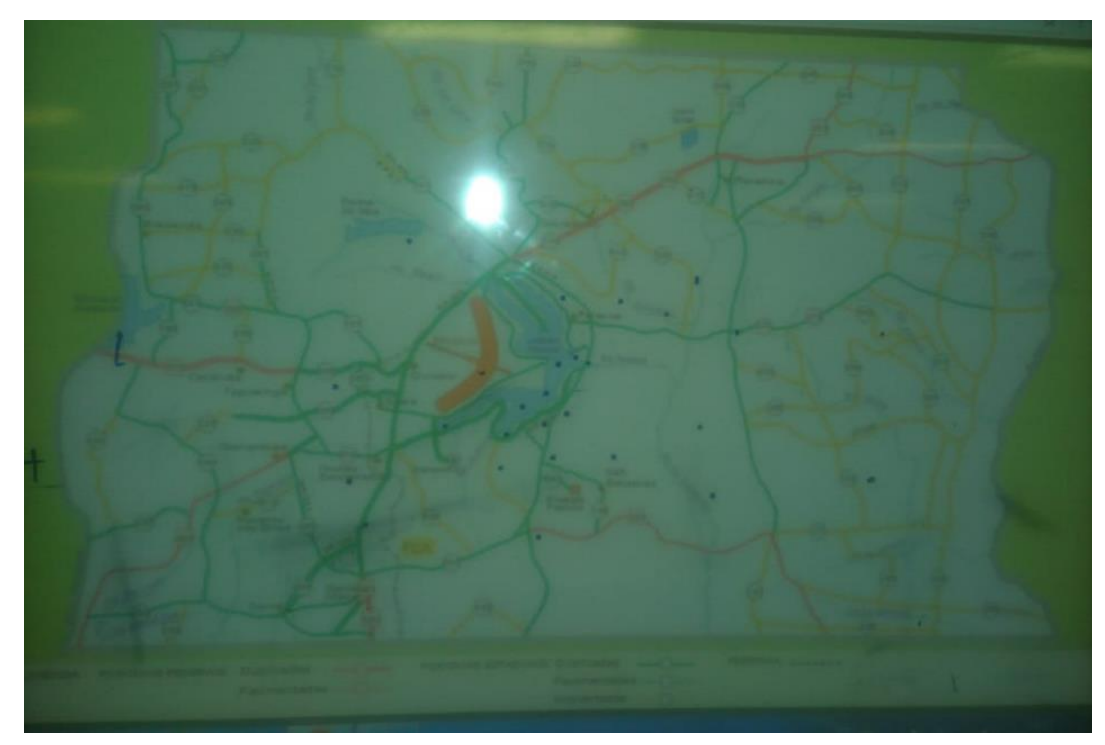

Figura 8: Foto tirada da observação da relação entre as principais estradas e os pontos de interesses escolhidos.

Fonte: Arquivo pessoal.

No entanto, ao verificar as relações entre as estradas e os pontos de interesses, observou-se que estas não criariam uma boa jogabilidade, pois não passaria por todos os locais.

Tendo isso em visto, optaram, então, por fazer a ligação direta, como um "liga pontos" de modo a verificar se essa estratégia traria uma boa conexão entre os elementos do tabuleiro. Entretanto, ao final, notou-se que esse tipo de relação criou extrema confusão nas rotas do tabuleiro, não devendo ser utilizada.

Em consenso, os estudantes decidiram, então, mesclar as duas ideias, criando ligações dos pontos, mas não de forma aleatória, mas, sim, seguindo o caminho preexistente e que tivesse como centro, o Plano Piloto (Figura 9).

\footnotetext{
${ }^{3}$ Atividade utilizada normalmente com crianças que consiste em ligar aos pontos presentes no papel para forma uma imagem.
} 


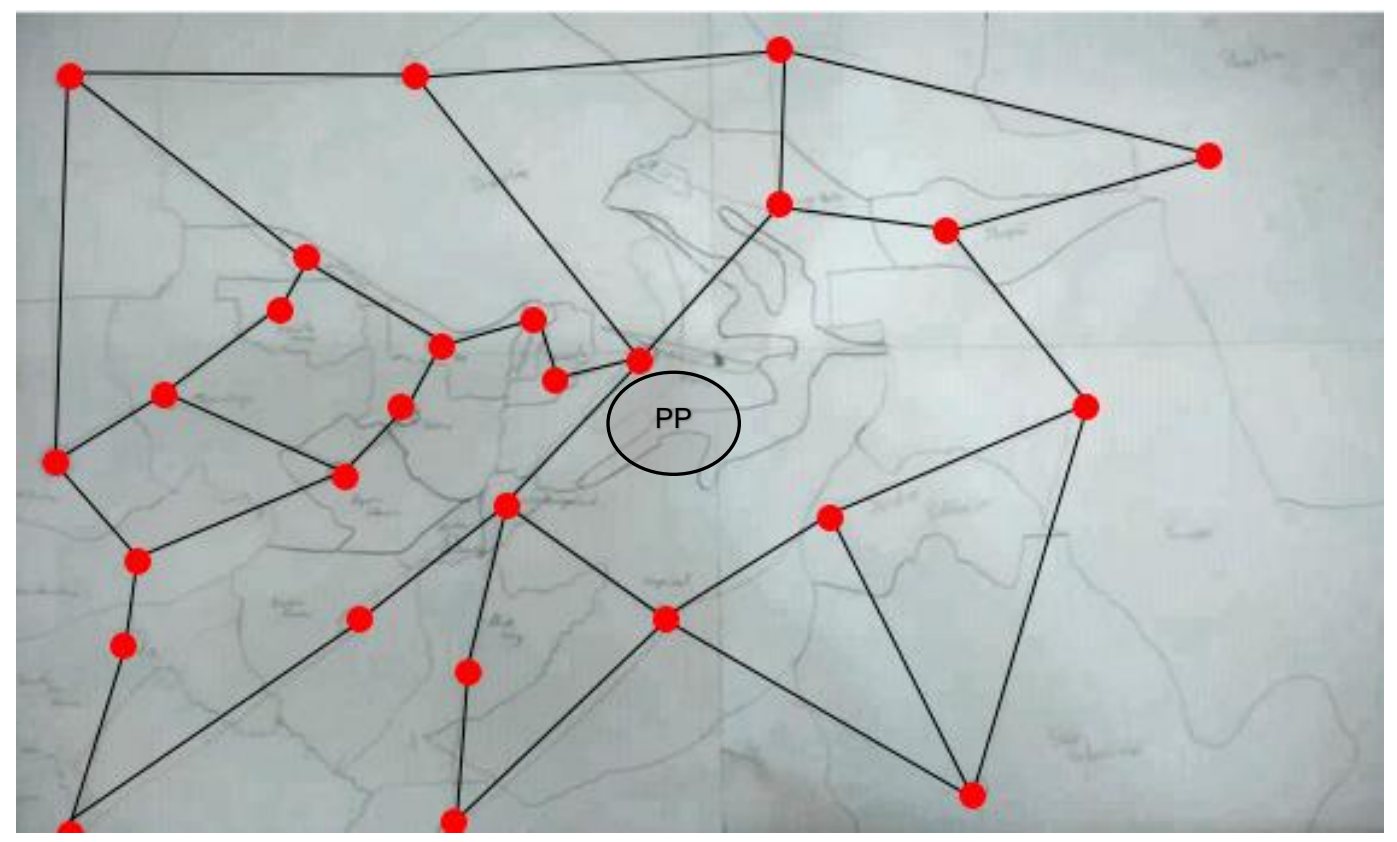

Figura 9: Relação entre as ligações e os pontos de interesse.

Fonte: Elaboração própria.

\subsection{Criação das regras do jogo:}

As regras dos jogos foram criadas em discussões realizadas por todos os participantes, para cada parte do jogo todos deram suas devidas opiniões respeitando as ideias dos demais, porém prevalecendo o consenso da maioria.

Após algumas reuniões e devido os aspectos gerais das regras, os próprios participantes delegaram funções que julgaram estarem mais aptos a realizarem, quem tinha mais contato com design optou em fazer os desenhos dos elementos como "personagens" e "tabuleiro". Quem estava em maior contato com jogos de tabuleiros optou por transcrever algumas das regras que haviam sido discutidos estruturando-as de acordo com o que é de costume em um jogo.

Sendo assim, o trabalho fluiu de forma natural entre os participantes do grupo, não havendo embate e todos respeitando as opiniões que eram expostas, se propondo a debatê-las e decidindo em grupo se era de interesse ou não, se condiziam com os aspectos que estavam sendo propostos, como, por exemplo, a discussão acerca da inclusão social. 
O primeiro resultado que foi alcançado com os alunos foi está exposto no Apêndice I, porém, as primeiras regras elaboradas por eles, ficaram demasiadamente complexas devido ao número de aspectos que eles gostariam de colocar no jogo para melhor representar o cenário real da vida urbana.

Todavia, chegou-se à conclusão de que daquela forma o jogo ficaria inviável para o entendimento e uso dos usuários, principalmente do público alvo do jogo. Dessa forma, após alguns debates e ajustes chegou-se ao seguinte resultado:

\subsubsection{Conteúdo do jogo}

O conteúdo que vem na caixa do jogo consiste em:

- 50 Cartas de pontuação;

- 25 Cartas da Cidade;

- 4 Cartas personagens;

- 30 Cartas de destino;

- 12 Dados de tempo;

- 6 Dados de grana;

- 6 Peões;

- 1 Tabuleiro;

- 1 Manual de instruções;

- 39 Notas de $\mathrm{R} \$ 20$;

- 39 Notas de $\mathrm{R} \$ 10$.

\subsubsection{Objetivo}

As dificuldades da mobilidade urbana no Distrito Federal atrapalham a todos. Pensando nisso, você deve ir do seu ponto de partida ao seu ponto de chegada levando em consideração os meios de transporte a serem utilizados e os problemas enfrentados na cidade, tentando adquirir o menor número de pontos negativos.

\subsubsection{Meios de transporte}

Durante toda a partida fica a cargo do jogador escolher entres os meios de transporte quais ele irá utilizar, levando em consideração suas consequências, são eles: 
- Bicicleta: A bicicleta é um veículo altamente ecológico e muito bom para fazer exercícios, seu deslocamento na cidade permite ir alugares que outros meios de transporte não vão, porém em um tempo mais longo.

Unidade de movimento: 1

Pontos negativos: 0 pontos.

Cor de referência: Verde.

- Ônibus: É o transporte público mais utilizado, pois consegue ir para quase todos os locais. Tem um deslocamento mais rápido que a bicicleta, porém emite mais poluente.

Unidade de movimento: 3

Pontos negativos: 2 pontos.

Cor de referência: Azul.

- Carro: É o veiculo de transporte muitas vezes mais utilizado, seu deslocamento é rápido, porém sua velocidade de agressão ao meio ambiente também é proporcional.

Unidade de movimento: 3

Pontos negativos: 2 pontos.

Cor de referência: Amarelo.

- Metrô: O metrô é um excelente transporte público, devido ao seu modo de locomoção ele possibilita um deslocamento mais rápido, porém só pode ser usado em locais específicos.

Unidade de movimento: 4

Pontos negativos: 1 ponto.

Cor de referência: Vermelho.

As cores de referência servem apenas como forma de facilitação do entendimento da movimentação do jogo, sendo que os meios de transporte podem andar por qualquer uma delas, exceto no caso do metrô, que sua utilização fica determinada exclusivamente para o local onde há a marcação de sua cor de referência (Vermelha). 
OBS: Nenhum meio de transporte pode ser utilizado por mais de 3 rodadas consecutivas, salvo quando o dinheiro acabar. Neste caso fica aceito a utilização da bicicleta quantas vezes forem necessárias.

\subsubsection{Preparando o jogo}

- Abra o tabuleiro em uma superfície plana;

- Cada grupo de jogador deve pegar uma carta personagem, sendo que, o jogo pode ocorrer individualmente (cada jogador escolhe um personagem) ou por grupo (criasse duplas, trios, quartetos entre outros, para competirem entre si, cada qual com 1 único personagem);

- O grupo deve escolher um peão para representa-lo;

- Cada grupo deve retirar uma carta de destino de partida e uma carta de destino de chegada, determinando assim de onde e para onde ele deve ir; - Cada grupo deve escolher dois dados de mesma cor para representarem seu tempo de jogo e escolher um dado de cor diferente para representar seu dinheiro;

\subsubsection{Começa a partida!}

Os grupos de jogadores devem lançar o dado de dinheiro e multiplica-lo por 10 para identificar o valor a ser recebido. Assim sendo, se o dado cair no 5, o valor a ser recebido é $\mathrm{R} \$ 50$ (Dinheiro $=5 \times 10=50$ ).

Os grupos devem lançar os dados de tempo e soma-los para determinar o número de rodadas que eles possuem para chegar ao seu destino. Após lançar os dados, se for do interesse do jogador, ele pode jogar novamente o menor valor do dado, sendo esse o valor a ser considerado.

Dessa forma, se sair nos dados 4 e 6 , mas o jogador decidir lançar novamente o dado de valor 4 e, o mesmo, cair no valor 1 , seu tempo de jogo será de 7 rodadas $(6+1=7)$. Após esse primeiro momento de definição, iniciasse as rodadas de jogo.

O jogador deve escolher no tabuleiro que rota irá seguir, juntamente com qual meio de transporte ele vai usar (Bicicleta, Ônibus, Carro ou Metrô). Depois de relevar sua estratégia, ele deve jogar o dado para definir o tanto que irá movimentar. Basta multiplicar o número tirado no dado com o número de movimento do transporte e terá 
o número de casas para andar, por exemplo, caso tenha escolhido o carro e tire um número 5 no dado, irá multiplicar o 5 pelo 3 (unidade de movimento do carro), dessa forma, andará 15 casas.

No tabuleiro há marcações que facilitam as movimentações dos transportes. Basta observar a cor que representa o seu meio de transporte e andar as casas necessárias. Dessa forma, se tiver com o carro e tirou 1 no dado, não precisa multiplicar por 3 , basta observar até onde corresponde uma linha amarela (representação do movimento do carro no tabuleiro) e fazer o movimento.

Caso o jogador pare em algum ponto da cidade ou passe por ele durante sua movimentação, ele deve retirar uma carta da cidade e observar sua consequência, seja ela boa ou ruim. Após isso é a vez do próximo jogador ou grupo.

*Para facilitar - Caso na carta da cidade fale que o jogador perdeu uma rodada de jogo, basta ele diminuir um número do dado de tempo, dessa forma ele poderá continuar jogando, pois, seu tempo já foi descontado. *

O jogo continua até acabarem os pontos de rodadas de todos os jogadores, ou, se o primeiro grupo chegar ao seu ponto de destino e após 3 rodadas seus adversários ainda não tiverem chegado aos seus destinos. Neste caso o jogo é finalizado.

\subsubsection{Vencedor!}

Vence aquele que conseguir chegar ao seu destino acumulando o menor número de pontos negativos possível. Caso haja empate no número de pontos, o primeiro que chegou no seu ponto de destino é considerado o vencedor.

\subsection{Teste das regras do jogo:}

Com o intuído de observar a interação dos participantes com o jogo propriamente dito e o andamento do mesmo em relação ao entendimento das suas regras, criaram-se algumas rodadas de jogo - 2 rodadas com 2 partidas cada, totalizando 4 partidas.

\subsubsection{Primeira rodada:}

A primeira rodada do jogo ocorreu no dia 08/06/2018, sendo realizado 2 partidas, tendo como participantes duas duplas, totalizando 4 participantes.

- Primeira partida: 
A primeira partida ocorreu de acordo com as regras pré-estabelecidas, por coincidência, as duas duplas pegaram pontos de partidas e destino próximos, ou seja, demandariam poucas rodadas para a finalização do jogo.

A proximidade dos destinos criou, nos participantes, um certo nível de comodidade, fazendo com que não houvesse um grau elevado de pensamento crítico em suas jogadas, moldando-as apenas na maneira mais fácil de se alcançar a vitória, gerando, assim, uma alta repetição de um meio de transporte, o que deixou o jogo monótono. Ressalta-se que essa é uma atitude inata do ser humano, por milhares de anos o seu organismo desenvolveu meios de guardar, ou seja, poupar energia (SELINGER, O'CONNOR, WONG e DONELAN, 2015), sendo verificado desde o jeito que se anda até a tomada de decisão, não sendo diferente quando o assunto trata-se do meio de locomoção.

Sendo assim, essa atitude apenas espelha o comportamento diário das pessoas que vivem nas cidades brasileiras, que é a escolha do carro como meio de transporte, na grande parte das vezes para um deslocamento curto, inconscientemente, apenas para evitar se exercitar, ou seja, focando na comodidade. A diferença que no jogo há a colocação de uma variável que não há no cotidiano, "a vitória", desta forma, o meio de transporte escolhido foi a "bicicleta", pois com a distância curta, esta seria a forma mais fácil para se alcançar o objetivo final.

Portanto, a partir da análise desse ocorrido, decidiu acrescentar a seguinte regra: "todos os meios de transporte só poderão ser utilizados 3 vezes seguidas".

No decorrer do jogo foram feitas algumas alterações no jogo a fim de facilitar o andamento da partida, como:

- Diminuição de 3 para 2 o número de "Dados de Tempo", sendo que o jogador tem direito de repetir o lançamento do dado de menor valor, se assim desejar;

- Multiplicar o valor retirado no "Dado da Grana" por 10. Ex: Jogador tira 6 no dado, esse valor é multiplicado por 10 para totalizar $\mathrm{R} \$ 60,00$ de grana;

- Retirada do meio de deslocamento "a pé" - Notou-se que "a bicicleta" e o "a pé" possuem efeitos semelhantes, mas "a bicicleta" gera maior interação ao jogo; 
- Alteração nos valores do transporte - os valores dos transportes foram alterados 2 vezes durante a partida a fim de melhor adaptar os valores à jogabilidade (Tabela 1);

Tabela 1: $1^{\mathrm{a}}$ e $2^{\mathrm{a}}$ alteração dos valores dos meios de transporte

\begin{tabular}{|l|c|c|c|}
\hline MEIO DE TRANSPORTE & INICIAL. & 1a ALTER. & 2a ALTER. \\
\hline ÔNIBUS & 1 & 10 & - \\
\hline CARRO & 5 & 20 & - \\
\hline METRÔ & 3 & 25 & 30 \\
\hline
\end{tabular}

- As cidades de partida e destino devem possuir, no mínimo, 2 cidades de distância;

- Alteração das unidades dos transportes (Tabela 2).

Tabela 2: Todas as alterações dos valores dos meios de transporte

\begin{tabular}{|l|c|c|c|c|c|}
\hline MEIO DE TRANSPORTE & INICIAL. & $\begin{array}{c}\text { 1a } \\
\text { ALTER. }\end{array}$ & $\begin{array}{c}\mathbf{2}^{\mathbf{a}} \\
\text { ALTER. }\end{array}$ & $\begin{array}{c}\mathbf{3}^{\mathbf{a}} \\
\text { ALTER. }\end{array}$ & 4a ALTER. \\
\hline BICICLETA & 2 & 1 & - & - & - \\
\hline ÔNIBUS & 3 & 2 & - & - & - \\
\hline CARRO & 3 & - & 4 & - & - \\
\hline METRÔ & 4 & 6 & $\times 3$ & $\times 2$ & $\begin{array}{c}\text { De cidade } \\
\text { em cidade }\end{array}$ \\
\hline
\end{tabular}

Por consequência das observações que foram notadas quando os pontos de referência estavam próximos, optou-se por fazer a segunda partida com os pontos de partida e chegada mais distantes possíveis de modo a verificar se haveria diferença na relação dos participantes com o jogo e entre eles.

- Segunda partida:

$\mathrm{Na}$ segunda partida foram utilizadas as novas regras desenvolvidas na partida anterior. Com o decorrer do jogo notou-se uma grande diferença com relação a interação dos jogadores com o jogo. $O$ fato de o deslocamento agora ser maior gerou nos jogadores um maior critério crítico para suas ações, pois agora estavam levando em consideração todos os aspectos do jogo, como nível de pontos negativos que o 
meio de transporte possuía, "grana" que possuíam, número de vezes que poderiam usar o transporte, além do aumento da competição entre as duplas, o que acarretou em um envolvimento ainda maior no jogo.

Essa partida demonstrou um outro fato muito relevante que ocorre na vida da cidade, que quanto maior o deslocamento, e dependendo dos recursos que são oferecidos, a tomada de decisão se torna mais estratégica, no sentido de poupar recursos e ao mesmo tempo agilizar o percurso. Tendo assim, um planejamento prévio das ações que se deve fazer.

Observou-se então que na segunda partida houve uma crítica maior do que poderia ser mais útil, até que ponto um certo tipo de meio de transporte poderia prejudicar o jogador, como conciliar diferentes meios de transporte para ter uma maior efetividade em seu deslocamento, como aliar a necessidade de recursos (como a "grana") com um deslocamento mais rápido através do uso consciente de meios de transporte mais práticos.

Na segunda partida houve alterações pontuais, tais como:

- A diminuição do custo do metrô e o aumento do valor referente ao carro (Tabela 3);

Tabela 3: Alterações pontuais nos valores dos meios de transporte

\begin{tabular}{|l|c|c|c|c|}
\hline MEIO DE TRANSPORTE & INICIAL. & 1a ALTER. & 2a ALTER. & 2a partida - 3a ALTER. \\
\hline ÔNIBUS & 1 & 10 & - & - \\
\hline CARRO & 5 & 20 & - & 50 \\
\hline METRÔ & 3 & 25 & 30 & 20 \\
\hline
\end{tabular}

- A determinação de que se o primeiro grupo chegar ao ponto de destino, os demais grupos têm apenas 3 rodadas para chegar ao seu ponto de destino, caso contrário, serão automaticamente eliminados.

\subsubsection{Segunda rodada:}

A segunda rodada do jogo ocorreu no dia 29/06/2018, sendo realizada 2 partidas, tendo como participantes duas duplas, totalizando 4 participantes.

- Primeira partida 
A primeira partida da segunda rodada foi realizada em dupla. Com as alterações realizadas no jogo, consequentemente, essa partida acabou sendo mais envolvente por parte dos jogadores, deixando-os mais imersos na proposta do jogo, ao ponto de pensarem e planejarem como poderiam se locomover pelo tabuleiro (cidade) da forma mais eficiente possível.

Nesta partida, houve apenas duas alterações a fim de otimizar os meios de transporte utilizados no jogo:

- Alterou-se o valor do carro de 50 para 30 (Tabela 4);

Tabela 4: Alteração do valor do meio de transporte - carro

\begin{tabular}{|l|c|c|c|c|c|}
\hline MEIO DE TRANSPORTE & INICIAL. & 1a ALTER. & 2 a ALTER. & $\begin{array}{c}\text { 2a partida } \\
-3 \underline{a} \\
\text { ALTER. }\end{array}$ & $\begin{array}{c}\text { 3a partida } \\
-4 \underline{a} \\
\text { partida. }\end{array}$ \\
\hline ÔNIBUS & 1 & 10 & - & - & - \\
\hline CARRO & 5 & 20 & - & 50 & 30 \\
\hline METRO & 3 & 25 & 30 & 20 & 20 \\
\hline
\end{tabular}

- Mudou-se a quantidade de pontos negativos do metrô, de 3 para 2, e aumentou-se a pontuação negativa do carro, de 3 para 4 (Tabela 5);

Tabela 5: Alteração dos pontos negativos do metrô e do carro

\begin{tabular}{|l|c|c|}
\hline MEIO DE TRANSPORTE & INICIAL. & 1a ALTER. \\
\hline ÔNIBUS & 1 & - \\
\hline CARRO & 3 & 4 \\
\hline METRO & 3 & 2 \\
\hline
\end{tabular}

- Criou-se um critério de desempate caso o número de pontos negativos seja semelhante: o primeiro jogador a completar o objetivo ganha. 


\section{CONSIDERAÇÕES FINAIS}

\subsection{Conclusões}

A forma como se planejam o sistema de transporte em âmbito nacional, enfatiza-se, quase que exclusivamente, o modo motorizado. Em se tratando de uma cidade construída sob o viés modernista, Brasília, que setoriza a distribuição dos elementos que compõem a cidade por meio de suas funções, acaba por isolar as pessoas, tornando-as dependentes do maior símbolo da tecnologia de sua época - o automóvel - que tem o papel de conectar tais setores (MORSHED, 2004), acaba por ser notório sua transformação em uma "Cidade do Automóvel" (COSTA, 2014). Assim, incentivase cada vez mais o uso deste meio, deixando em segundo plano, ou até mesmo à parte da vida da cidade, quem não o utiliza - o pedestre.

Esse conjunto de ações acaba por provocar um efeito em cadeia, acarretando na morte da vida na cidade (JACOBS, 2000). Para que tal ciclo seja quebrado e tais consequências sejam desfeitas, o incentivo à participação coletiva no entendimento $e$ tal como na elaboração das condições que favorecem a constituição da cidade deve ser enfatizado (SADIK-KHAN E SOLOMONOW, 2016; KENT, 2015).

Dessa forma, a estimulação do público mais jovem para um pensamento mais crítico perante suas ações no tocante ao seu deslocamento pela cidade se faz indispensável. E é neste contexto que esta pesquisa visou verificar em que medida estratégias lúdicas (como os jogos e as brincadeiras) podem estimular jovens e crianças a absorverem informações.

Constatou-se que os jovens - participantes desta pesquisa - estão mais abertos às mudanças de pensamento e possuem uma maior intimidade com as ideias que propiciam a melhoria das condições que favoreçam o uso dos espaços pelas pessoas, como o incentivo da utilização do transporte público e não o motorizado individual. No entanto, cabe pontuar que o fato deste grupo de alunos fazerem parte de uma escola de classe média alta, a visão crítica é estimulada com base em toda a estrutura educacional que já adquiriram e, certamente, continuarão a adquirir. 
Tendo em vista a mudança de pensamento que, por sua vez, vem da aprendizagem de novas informações, porém em um sistema que se utiliza de métodos do séc. XVIII, acaba por criar um desinteresse no tocante a busca e a assimilação de novas informações (CORTELLA, 2014). Dessa forma, estratégia lúdicas despertam uma maior compreensão dos jovens por proporcionar maior participação e interação dos mesmos na hora do ensino ou por apresentar novas formas que permitam eles apresentarem seus questionamentos e indagações, quando já possuem uma visão crítica do mundo que os cercam - que foi o caso observado na pesquisa.

Esse desejo inato por espaços que possam usufruir desenvolveu nos jovens uma percepção crítica bem ampla no que se refere a mobilidade urbana, sendo que, durante toda a pesquisa esse olhar crítico para os pontos específicos se manteve, necessitando apenas, que fosse incentivado a livre expressão de suas opiniões, como no caso do Grupo Focal.

Em relação às discursões sobre as regras do jogo, pensou-se no modo como ocorre o funcionamento da cidade, os pontos de referência que criam maior impacto para as pessoas e como poderiam se desenvolver, no tocante à mobilidade, procurando inserir uma consciência analítica para dentro do jogo, e não levando em consideração elementos baseados somente na sorte e aleatoriedade. À vista disso, notou-se haver uma alteração na visão dos jovens em relação aos jogos, ou seja, inseriu-se um direcionamento e incentivo ao desenvolvimento da visão de todos os participantes.

Durante todo o processo, observou-se a interação dos jovens com os questionamentos levantados perante a forma que se dá a constituição do atual panorama da mobilidade na cidade de Brasília. Ressalta-se que eles buscavam apresentar suas opiniões e indagações fazendo, inclusive, assimilações com outras áreas do conhecimento para defender seu posicionamento, sempre levando as colocações contrárias à sua ideia, por parte de um colega, como uma nova maneira de enxergar o problema e não como um meio de criar um embate.

Levando em consideração essa atitude, inclusive, nas alterações realizadas nas regras do jogo durante o período de teste, notou-se que devido a alguns fatores levantados pelos participantes - como o fácil entendimento do jogo e suas regras por parte de futuros jogadores e também a preservação da mobilidade do jogo e da visão crítica das jogadas - era necessário fazer adaptações às regras do jogo. 
Esses levantamentos foram realizados e discutidos por todos os participantes e a questão do que seria melhor ou pior foi resolvida por meio do debate de ideias e da argumentação, tendo em conta o bom senso e a opinião de todos, prevalecendo sempre a opinião da maioria, sem que houvesse conflito por parte dos mesmos, demonstrando, assim, um grande exemplo de democracia e do poder do grupo.

Vale salientar que o produto final (o jogo), transmite a visão crítica presente nos jovens desde o Grupo Focal, em que deve-se, sim, pensar na forma como se pode locomover de acordo com a necessidade que se possui para que não se prejudique todo o ecossistema no qual compõem-se a cidade em si, levando em consideração todo e qualquer meio de locomoção, sempre com a visão crítica de cada um sem benefício e malefício e devendo-se saber o momento adequado de se utilizar cada um deles.

Ressalta-se, portanto, que tal resultado comprova que as estratégias lúdicas de ensino propiciam um maior interesse dos jovens em apresentar e assimilar seus conhecimentos em relação às tradicionais, em que o conteúdo é apenas transmitido aos alunos de forma unilateral pello professor, como uma espécie de emissor e não como um incentivador da pesquisa e da aprendizagem.

\subsection{Recomendações}

O fato da instituição necessitar realizar pesquisas júniores com instituições parceiras, acaba por restringir o público, ou seja, seria muito interessante realizar esta pesquisa em instituições de ensino médio situadas fora do polígono do Plano Piloto, em que os estudantes apresentam além de uma visão diferenciada em relação à mobilidade na cidade, certamente que devido o menor nível de renda, faz com que a visão crítica para determinados aspectos seja menos aguçada.

Outro aspecto relevante, seria a aplicação desta pesquisa com crianças, mas tomando as devidas proporções, uma vez que os procedimentos metodológicos devem adequar-se ao grau de desenvolvimento desta fase da vida. 


\section{Referências Bibliográficas}

BERNARD VAN LEER FOUNDATION. Small children, Big City: impact through design intervention. New Delhi, India. 2014. Disponível em: https://bernardvanleer.org/solutions/urban95. Acesso em: Maio de 2017.

CALDEIRA, T. Cidade de muros: crime, segregação e cidadania em São Paulo. São Paulo: EdUSP, 2000.

CORTELLA, Mario Segio. Educação, escola e docência. Novos tempos, novas atitudes. São Paulo: Cortez, 2014.

COSTA, Emannuel. A cidade do automóvel: Relações de influência entre o carro e o planejamento urbano modernista em Florianópolis. Dissertação de Mestrado. Universidade Federal de Santa Catarina, 2014.

GEHL, J. Cidades para pessoas. São Paulo: Perspectiva, 2010.

GONDIM, S. M. G. Perfil profissional e mercado de trabalho: relação com formação acadêmica pela perspectiva de estudantes universitários Estudo Psicologia, Natal, v. 7, n. 2, 2002.

HAARHUIS, H. Child in the city. Child in the City Conference. Ghent (Belgium). 2016. Disponível em:

https://www.childinthecity.org/2016-conference/conference-programme/. Acesso em: maio de 2017.

HEEMANN, J. e Santiago, P. C. Guia do espaço público para inspirar e transformar. Mountain View (CA), USA, 2015.

JACOBS, J. Morte e vida de grandes cidades. São Paulo: Martins Fontes, 2000.

KENT, F. Sustainable Urban Mobility Plans: planning for people. 2005. Disponível em: http://mobilityplans.eu/docs/file/SUMP_Brochure_EN_final_web.pdf. Acesso em: jan de 2014.

KITZINGER, J. Focus groups with users and providers of health care. In: POPE, C.; MAYS, N. (Org.). Qualitative research in health care. 2. ed. London: BMJ Books, 2000.

MAGNANI, J. G. Rua, símbolo e suporte da experiência urbana. Publicado em Cadernos de História de São Paulo 2, Museu Paulista-USP, 1993.

MORSHED, Adnan. The Aesthetics of Ascension in Norman Bel Geddes's Futurama. Journal of the Society of Architectural Historians, Vol. 63, No. 1. Society of Architectural Historians, 2004. p. 74-99.

PEIRCE, C.S. Semiótica. São Paulo: Perspectiva, 2010.

SADIK-KHAN, J. e SOLOMONOW, S. Streetfight: Handbook for an Urban Revolution. USA: Pinguin USA, 2016.

SCRIMSHAW, S.; HURTADO, E. Anthropological approaches for programmes improvement. Los Angeles: University of California Press, 1987.

SELINGER, J. C., O'Connor, S. M., Wong, J D., and Donelan, J. M. Humans Can Continuously Optimize Energetic Cost during Walking, Burnaby, Department of Biomedical Physiology and Kinesiology, Simon Fraser University, 2015. 
SPECK, J. Cidade Caminhável. São Paulo: Perspectiva, 2016.

TRAD, L. Grupos focais: conceito, procedimentos e reflexões baseadas em experiências com o uso da técnica em pesquisas de saúde. Physus vol.19, no.3; Rio de Janeiro, 2009.

VANDERBILT, T. Por que dirigimos assim? E o que isso diz sobre nós. Mitos, Verdades e curiosidades sobre o trânsito. Rio de Janeiro: Elsevier, 2009.

WHYTE, W. The social life of small urban spaces. New York: Project for Public Spaces, 1980. 


\section{Apêndice I}

Primeira regra desenvolvida pelos participantes:

\section{I.Objetivo}

Tese: As dificuldades da mobilidade urbana no Distrito Federal atrapalham a todos. Para remediar isso, é necessário análise e cooperação.

Público-alvo: Infanto-juvenil.

Complexidade: O jogo deve conter o mínimo de complexidade necessária para despertar a estratégia e a crítica nos jogadores, se mantendo simples o suficiente para não se tornar excessivamente lento, pesado ou confuso e, por consequência, afastar o público-alvo.

Tipo de jogo: Jogo cooperativo de tabuleiro.

\section{II.Os Elementos do Jogo}

Os elementos do jogo são essenciais para entender as regras. Abaixo, eles são listados e explicados. Nota: os elementos estão entre colchetes [] para destacálos do texto.

- A [jornada];

- Um [mapa];

- Os [locais];

- A [partida] e o [destino];

- Várias [rotas];

- Os [pontos de coleta];

- A sua [grana];

- Os [jogadores];

- A [personagem];

- $\mathrm{O}$ [motivo];

- O [horário];

- O fator [tempo]; 
- Os [pontos] e a [margem];

- A [cidade];

- As formas de [locomoção];

- Gasolina

\section{I.Jornada}

A jornada é um ciclo do jogo. Ela representa os vários atos de mobilidade que levam da partida até o destino. Para que os jogadores tenham sucesso, eles devem fazê-lo respeitando a margem.

\section{II.Mapa}

O mapa é o tabuleiro do jogo. Nele se encontram vários destinos e partidas possíveis para a personagem, além de pontos de rotas, pontos de ônibus, metrôs. Elementos do mapa podem ser modificados pelo horário.

\section{III.Local}

Um local é um ponto de interesse no mapa. Ele pode ser o edifício de uma empresa, um shopping mall, um hospital, um condomínio, uma estação de metrô, um restaurante... As possibilidades são limitadas pelo mapa.

\section{IV.Rota}

No mapa, os locais são ligados por rotas. É pelas rotas que a personagem se movimenta. A maior parte das rotas custa uma única rodada para serem atravessadas, mas esse custo está sujeito a modificações pela cidade, horário e locomoção.

\section{V.Partida e Destino}

A partida é o local inicial do personagem. Já o destino é o local alvo da personagem. Ambos determinados sacando cartas do baralho de locais na fase de preparação.

\section{VI.Pontos de Referência}

Pontos de coleta são pontos de ônibus e estações de metrô, a personagem pode gastar parte da sua grana para pegar um ônibus ou metrô, 
respectivamente. Cada um deles é um método de locomoção diferente, com propriedades únicas.

\section{VII.Grana}

A grana representa a quantidade de dinheiro que a personagem carrega. É uma medida abstrata, ou seja, não corresponde a um número exato em reais. $A$ grana é determinada na fase de preparação através da rolagem de dados. Grana é normalmente utilizada para pagar o transporte.

VIII.Jogadores

Um(a) jogador(a) é aquele(a) que se submete ao jogo. Ele(a) deve seguir as regras. Normalmente, há mais de um(a) jogador(a) (o número recomendado é entre 3 e 5), mas todos controlam apenas um personagem, devendo agir em conjunto e tomar decisões que ajudem tal personagem a se mover no mapa da forma mais harmônica, sustentável e viável possível.

IX.Personagem

Neste jogo, todos os jogadores do grupo controlam um único personagem. Cada personagem possível tem propriedades únicas, adicionando fatores particulares à jornada. O personagem é determinado sacando uma carta do baralho de personagens na fase de preparação.

\section{X.Motivo}

O motivo é a causa da jornada, ou seja, o porquê de o personagem querer atingir o destino. Ele pode estabelecer um objetivo secundário ou restrições adicionais para a jornada.

\section{XI.Horário}

O horário determina em que parte do dia o jogo está ocorrendo. Para os propósitos do jogo, há dois horários possíveis: pico e entre pico. O horário é determinado na fase de preparação jogando um dado.

XII.Tempo

Os jogadores são limitados pelo tempo, o qual é medido em rodadas. Na fase de preparação, os jogadores determinam o tempo disponível para a jornada 
jogando dados. Ultrapassar o limite implica na acumulação de pontos, mas estar abaixo dele não implica em qualquer subtração.

XIII.Pontos

Neste jogo, pontos são uma medida do sucesso do personagem (e por consequência, dos jogadores) em manter um trânsito harmônico, sustentável e viável. Quantos menos pontos um personagem acumula, mais próximo desse ideal ela está.

XIV.Cidade

A cidade representa os elementos fora do controle do personagem. A cada rodada, um dado é jogado para determinar se terá um efeito da carta cidade. Essa carta pode trazer benefícios ou malefícios.

XV.Locomoção

Há diferentes formas de locomoção, as quais são limitadas pelo seu personagem. Todos podem ser pedestres. Algumas locomoções se movem mais rápido que outras, porém só pode deixá-las em certos pontos. Outras locomoções danificam o ambiente.

XVI.Gasolina

Gasolina é um recurso especial. Caso comece o jogo com um carro ou uma moto, jogue os dados laranja. Esse é o seu valor de gasolina. Utilizar motos e carros implica no gasto de gasolina. Sem gasolina, é impossível utilizar tais veículos, e eles são perdidos. Gasolinas podem ser preenchidas em postos de gasolina.

\section{III.Regras}

Condição de Vitória: Para ganhar, a [personagem] deve viajar da [partida] até o [destino] obedecendo a quaisquer restrições estabelecidas pelo [motivo].

Condição de Derrota: Caso a [personagem] acumule um número de [pontos] maior que a [margem], os [jogadores] perdem.

Número de Jogadores: Idealmente, de 2 a 8. 
Fases: O jogo é dividido em duas fases: a fase de jogo e a fase de preparação. Fase de Preparação: Nesta fase, ocorrem os preparativos do jogo. Ela ocorre antes da fase de jogo, e se dá da seguinte maneira:

1. Quaisquer regras opcionais escolhidas são adotadas, se sobrepondo às regras originais.

2. Duas cartas do baralho de locais são puxadas: a primeira revela a [partida] e a segunda revela o [destino]. Caso haja 6 ou menos rotas de distância entre os dois [locais], embaralhe as duas cartas e repita este passo. Quando as cartas forem válidas, posicione a miniatura da [personagem] sobre a [partida].

3. Um único dado é jogado. Caso o resultado seja par, a [jornada] acontecerá em [horário] de pico. Caso o resultado seja ímpar, a [jornada] acontecerá em [horário] de entre picos.

4. Os três dados azuis são jogados. A soma deles é a [grana] disponível nesta [jornada].

5. Os três dados roxos são jogados. A soma deles é o [tempo] disponível nesta [jornada]

6. Uma carta do baralho de personagens é puxada, revelando quem será a [personagem] desta [jornada]. Aplique quaisquer modificações aos outros recursos agora.

7. Uma carta do baralho de motivos é puxada, determinando o [motivo] da [jornada]. Aplique quaisquer modificações aos outros recursos agora.

Fase de Jogo: Nesta fase, a [jornada] ocorre. Esta fase é após a fase de preparação, e se dá da seguinte maneira:

1. Os [jogadores] conferem a posição da [personagem] no [mapa].

2. Os [jogadores] determinam qual será o método de locomoção desta rodada.

3. Os [jogadores] debatem entre si a melhor forma de avançar o caminho da [personagem]. 
4. Os [jogadores] fazem qualquer ação especial referente à forma de [locomoção] atual.

5. Os [jogadores] locomovem a personagem o número adequado de [rotas], aplicando qualquer modificador proveniente do passo 2.

6. Os [jogadores] conferem se a [cidade] faz um movimento, jogando um dado.

A. Caso tenham tomado uma ação:

- Em um resultado de 2, 3, 4 ou 5, puxam uma carta do baralho da cidade;

- Em um resultado de 6, não puxam nenhuma carta;

- Em um resultado de 1, jogam o dado novamente.

B. Caso não tenham tomado uma ação:

- Em um resultado de 2, 3 ou 4, puxam uma carta do baralho da cidade;

- Em um resultado de 5 ou 6, não puxam nenhuma carta;

- Em um resultado de 1, jogam o dado novamente.

7. Os [jogadores] reduzem o [tempo] em 1 e aplicam quaisquer modificadores provenientes do meio de transporte utilizado, levando sempre em conta a carta da cidade.

8. Os [jogadores] concluem a rodada, e voltam ao passo 1.

Esta fase se repete até os jogadores perderem ou ganharem.

IV.Ações

Ações são movimentos especiais exclusivos a cada veículo. Você só pode tomar uma ação por rodada, e deve estar no veículo correto para tomar tal ação.

$\mathrm{Na}$ rodada em que deve ser retirado uma carta da cidade, o dado da cidade precisa tirar apenas 2, 3, 4 ou 5 para sofrer o efeito da carta. 


\section{V.Veículos}

Seja a pé, de bike, moto, camelô, cavalo... Você precisa chegar no seu destino de alguma forma. Abaixo, as informações sobre cada forma de veículo são enunciadas. Com elas, ações especiais e regras particulares. Nota: Talvez seja interessante incluir mais modos de locomoção, ou transformar a ação Pegar um $U^{* *} r$ em um veículo separado, ou enunciá-lo por si só.

I.Pé

O pé é a mais antiga forma de locomoção da humanidade. Andar a pé não consome nenhum dos seus recursos. Andar a pé te concede as seguintes ações especiais:

- Correr: Ao tomar a ação de correr, você pode se deslocar uma rota adicional, durante uma única rodada. Ademais, caso o dado jogado para determinar se a cidade se move resulte em 2, 3, 4 ou 5 durante a rodada na qual você tomou esta ação, deve puxar uma carta do baralho da cidade. Ademais, caso o dado jogado para determinar se a cidade se move resulte em 2, 3, 4 ou 5 durante a rodada na qual você tomou esta ação, deve puxar uma carta do baralho da cidade.

- Use o app: Usar o app é uma ação especial. Na rodada que a toma, não pode atravessar qualquer rota. Na próxima rodada, um carro chega à sua localização. Este carro pode te levar a qualquer local no mapa, porém você deve pagá-lo um de grana por rota atravessada. Usar o app implica, além do pagamento de grana, que você ganha 1 ponto por rodada utilizando o veículo do app.

\section{II.Bicicleta}

A bicicleta é um dos modos mais eco-amigáveis de se locomover, além de ser saudável e divertido. Assim como andar a pé, andar de bicicleta não consome nenhum dos seus recursos. Apesar disso, ciclovias não são tão comuns quanto deveriam ser. Independente de tomar uma ação ou não, você puxa uma carta da cidade caso o dado resulte em 2, 3, 4 ou 5. Andar de bicicleta te concede as seguintes ações especiais: 
- Sprint!: Ao tomar a ação de sprint!, você pode se deslocar uma rota adicional durante um tempo ilimitado. Porém, você deve sempre se deslocar o número máximo de rotas até tomar a ação de stop!.

- Stop!: Você só pode tomar a ação de stop! se a está sobre o efeito da ação sprint!. Ao tomar a ação de stop!, você cancela a ação sprint!, voltando ao seu máximo normal. Durante a rodada na qual você toma esta ação, você pode e deve se deslocar apenas uma rota.

\section{III.Motocicleta}

A motocicleta é um veículo motorizado de menor peso e consumo. Ainda assim, é um estilo que custa ao ambiente e, dependendo de quem você é, à harmonia no trânsito. Durante horários de pico, a velocidade de uma moto é reduzida em 1 rota. Caso o recurso gasolina acabe, você perde a sua moto. Andar de motocicleta te concede as seguintes ações especiais:

- Maldito barbeiro: Caso tome a ação maldito barbeiro, ganha 4 pontos. Ademais, você aumenta o número máximo de rotas por rodada da motocicleta em 1.

\section{IV.Carro}

O carro é um jeito bem tradicional de passear por aí. Pode ser bem legal também, se seu carro for esportivo. Very stylish, son of a car, mas tome cuidado pra não ser um babaca com o ambiente. Ou com aquele seu vizinho que você quer matar.

Em horários de pico, a velocidade do carro é reduzida em uma rota. Caso o recurso gasolina acabe, você perde o seu carro. Andar de carro te concede as seguintes ações:

- Seja bom é o cacete!: Ao tomar a ação Seja bom é o cacete!, você ganha 4 pontos. Ademais, sua velocidade aumenta em uma rota, e você deve jogar um dado. Caso o resultado seja 2, 3 ou 4, você deve pagar 6 de grana. Caso o resultado seja 1, você deve pagar 10 de grana. Se não houver grana o suficiente para cobrir estas taxas, você perde o seu carro. 
Nota: tomar esta ação automaticamente te classifica como um completo babacão.

\section{V.Busão}

O busão é um jeito bem interessante de chegar nos lugares. Certamente é mais barato do que ficar pagando por gasolina o tempo inteiro, e bem mais acessível do que um carro e uma moto. Mais rápido que uma bicicleta ou, Deus me livre, ir a pé. O busão, porém, pode ser bem desconfortável, e aquela fumaça preta não deve ser muito boa pros pássaros... Em horários de pico, a velocidade do busão é reduzida em 1 rota. O busão só para em pontos de ônibus. Subir em um busão custa 2 de grana. Estar no busão não te concede nenhuma ação especial.

\section{VI.Metrô}

Dá certo com os japoneses, por quê não com nós, não é mesmo? O metrô é bem legal, mas tem uma rota bem limitada também. Ainda sim, pode ser mais rápido do que qualquer outro veículo. O metrô só para em estações de metrô, e segue um caminho pré-determinados e demarcados. Subir em um metrô custa 2 de grana. Estar no metrô não te concede nenhuma ação especial.

VII.Tabela

Cada veículo possui um valor de velocidade e uma quantidade de pontos que é acumulada a cada rodada o utilizando. Certos veículos consomem gasolina também.

\begin{tabular}{|l|c|c|c|}
\hline \multicolumn{1}{|c|}{ Veículo } & $\begin{array}{c}\text { Máximo de rotas por rodada } \\
\text { (Velocidade) }\end{array}$ & $\begin{array}{c}\text { Pontos por } \\
\text { rodada }\end{array}$ & $\begin{array}{c}\text { Gasolina por } \\
\text { rodada }\end{array}$ \\
\hline A pé & 1 & 0 & 0 \\
\hline Bicicleta & 2 & 0 & 0 \\
\hline Motocicleta & 3, mas é limitado pela gasolina & 3 & 1 \\
\hline Carro & 3, mas é limitado pela gasolina & 2 & 2 \\
\hline Ônibus & $\begin{array}{c}\text { Viaja sempre 3, a não ser que } \\
\text { haja um ponto de coleta }\end{array}$ & 2 & 0 \\
\hline Metrô & $\begin{array}{c}\text { Viaja sempre 4, a não ser que } \\
\text { haja um ponto de coleta }\end{array}$ & 1 & 0 \\
\hline
\end{tabular}




\section{VI.Locais}

Locais são partidas, destinos e paradas. Certos locais podem ter propriedades especiais ativadas quando a personagem passa por eles. Todos os locais são representados no mapa. Abaixo, algumas sugestões de possíveis locais.

\section{I.Ponto de Ônibus}

Para efeito de simplicidade, todos os busões passam pelo ponto de ônibus. É de lá que eles partem e é lá que eles chegam. Em um ponto de ônibus, pode pagar 2 de grana para subir em um busão. Quando o faz, caso ainda tenha movimento restante, sua velocidade é reduzida em 1, apenas pelo restante daquela rodada.

\section{II.Estação de Metrô}

Estações de metrô são diferentes de pontos de ônibus. Em pontos de ônibus, a personagem pode se deslocar em qualquer rota, desde que deixe o ônibus em outro ponto. Já metrôs seguem rotas especiais coloridas, mas também devem terminar em estações de metrô. Em uma estação de metrô, pode pagar 2 de grana para subir em um metrô. Quando o faz, caso ainda tenha movimento restante, sua velocidade é reduzida em 1, apenas pelo restante daquela rodada.

\section{III.Posto de Gasolina}

Ah, gasolina. Realmente não presta. Caso a sua esteja acabando e você seja desses burguesinhos que anda de carro e moto, porém, você pode querer um refill. Em um posto de gasolina, caso tenha um carro ou uma moto, pode trocar grana por gasolina, em uma razão de 1:1. Caso ainda tenha algum movimento restante na rodada em que enche seu tanque, sua velocidade é reduzida em 1, apenas pelo restante daquela rodada.

\section{IV.Escola}

Uma instituição de aprendizado, sofrimento e provas no sábado. Precisa de alguma prova maior de que estamos todos mortos e é este o Inferno? 


\section{V.Shopping Mall}

Lojas de roupa, cinema, livrarias, boys and girls and dogs... O shopping tem de tudo. Só tome cuidado, todas estas coisas brilhantes e opa... Caso esteja a pé ou de bicicleta e acabe sua rodada em um shopping mall, você perde 3 de grana. Este preço é aumentado para 5 se estiver de carro ou moto (estacionamento é caro, baby!).

\section{VI.Restaurante}

Bem, pode até ser, mas no sentido bem liberal da palavra. Quer dizer, na fome, até aquele tio na esquina vendendo esquilo no espeto pode parecer um MasterChef. De uma forma ou de outra, se revigorar é sempre bom. Caso esteja em um restaurante, pode gastar 4 de grana para aumentar sua velocidade em 1 rota. Este efeito dura 2 rodadas.

\section{VII.Igreja}

Alguns são creem por bem, outros por medo, outros só pra se prevenir, outros pra agradar a mulher... De uma forma ou de outra, muita gente vai à igreja.

\section{VIII.Parque}

Hoje em dia, a moda é outdoors. O negócio é vir pro parque pra correr, assistir as crianças, aproveitar a natureza ou só tirar foto pro insta mesmo. \#naturalpeople

\section{IX.Hospital}

Estabelecimento próprio que se destina ao tratamento e à internação de pessoas doentes ou feridas. 


\section{Apêndice II}

Conteúdo do jogo:

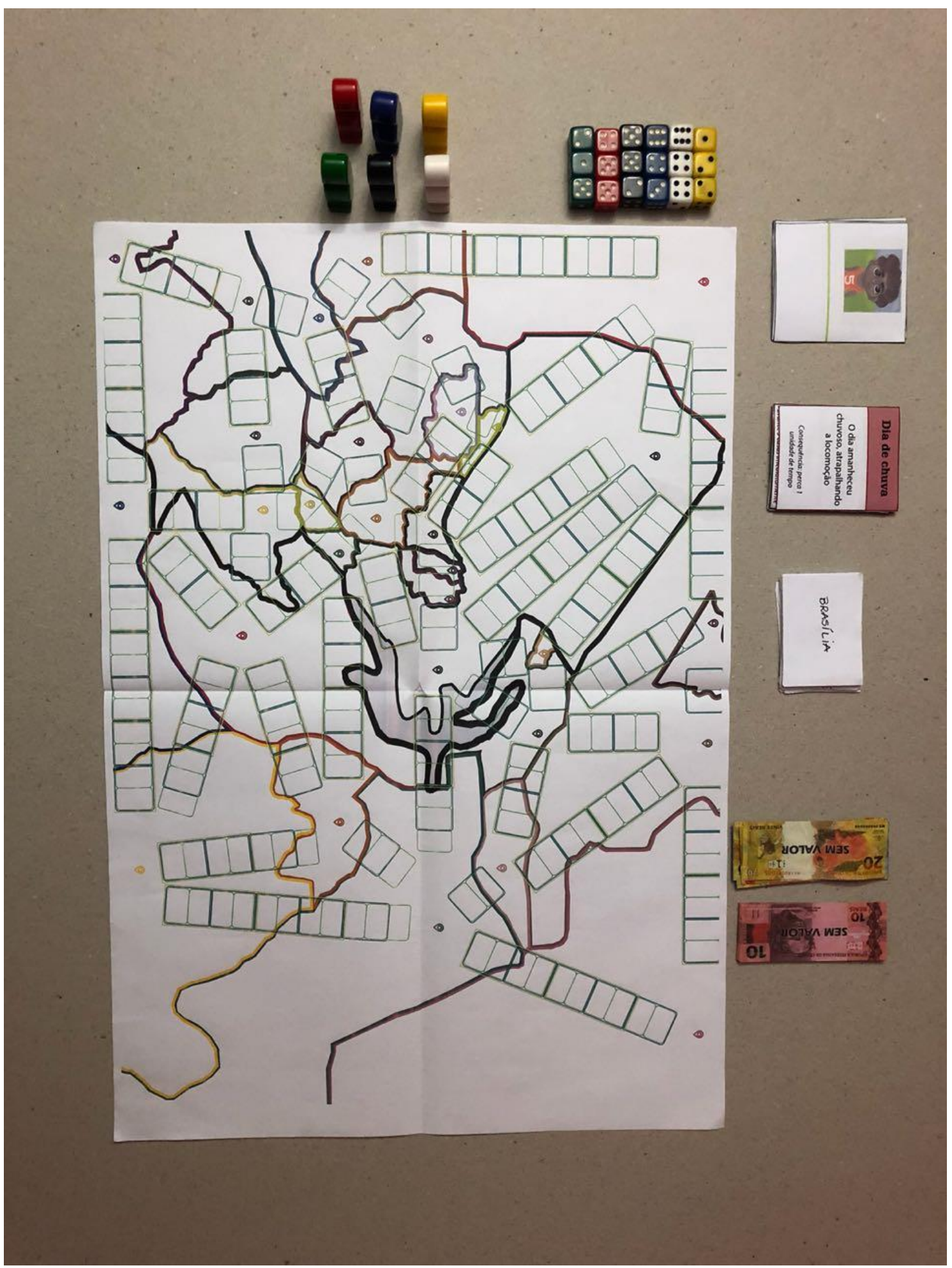

Figura 10: Elementos do Jogo. 


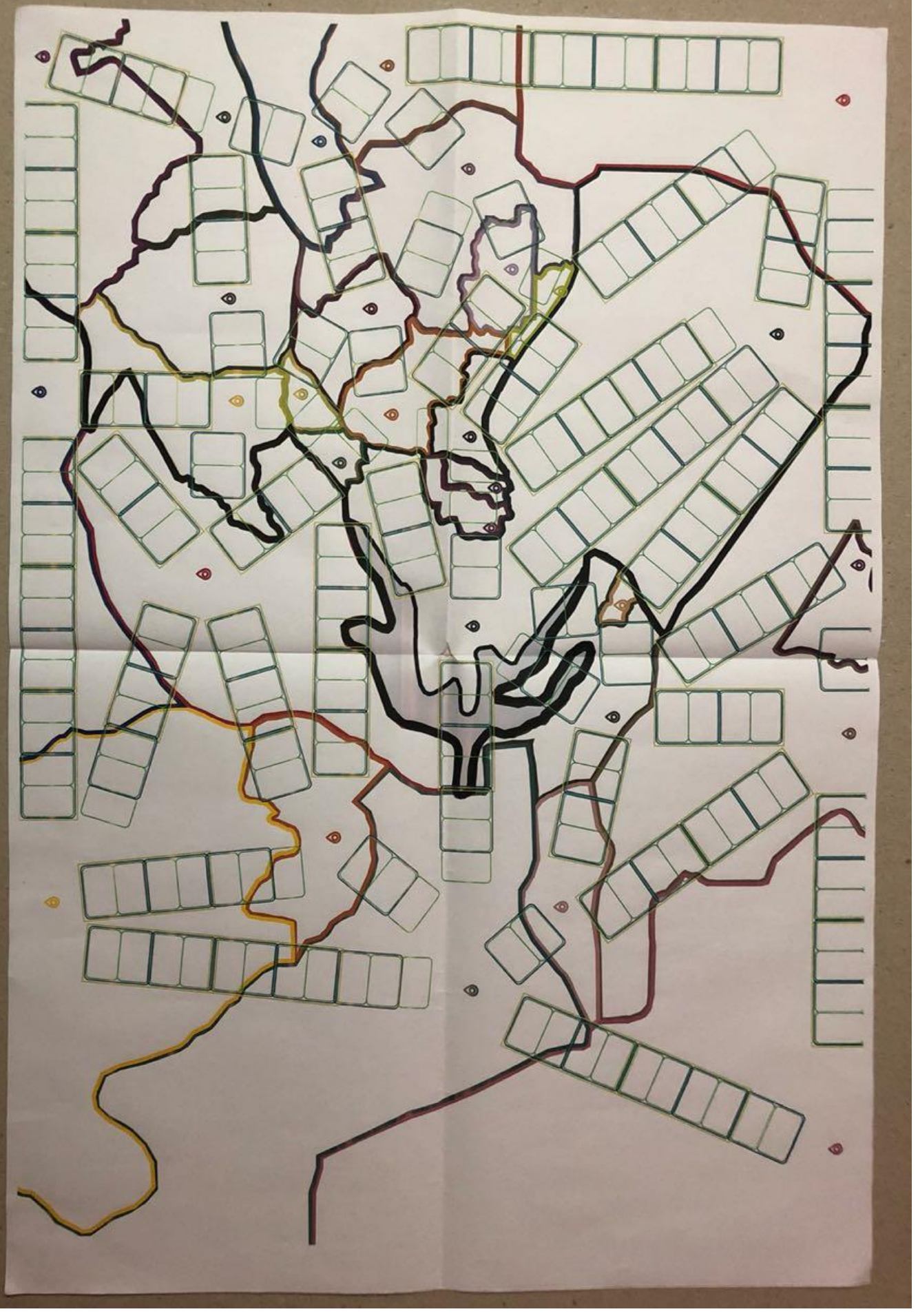

Figura 11: Tabuleiro. 


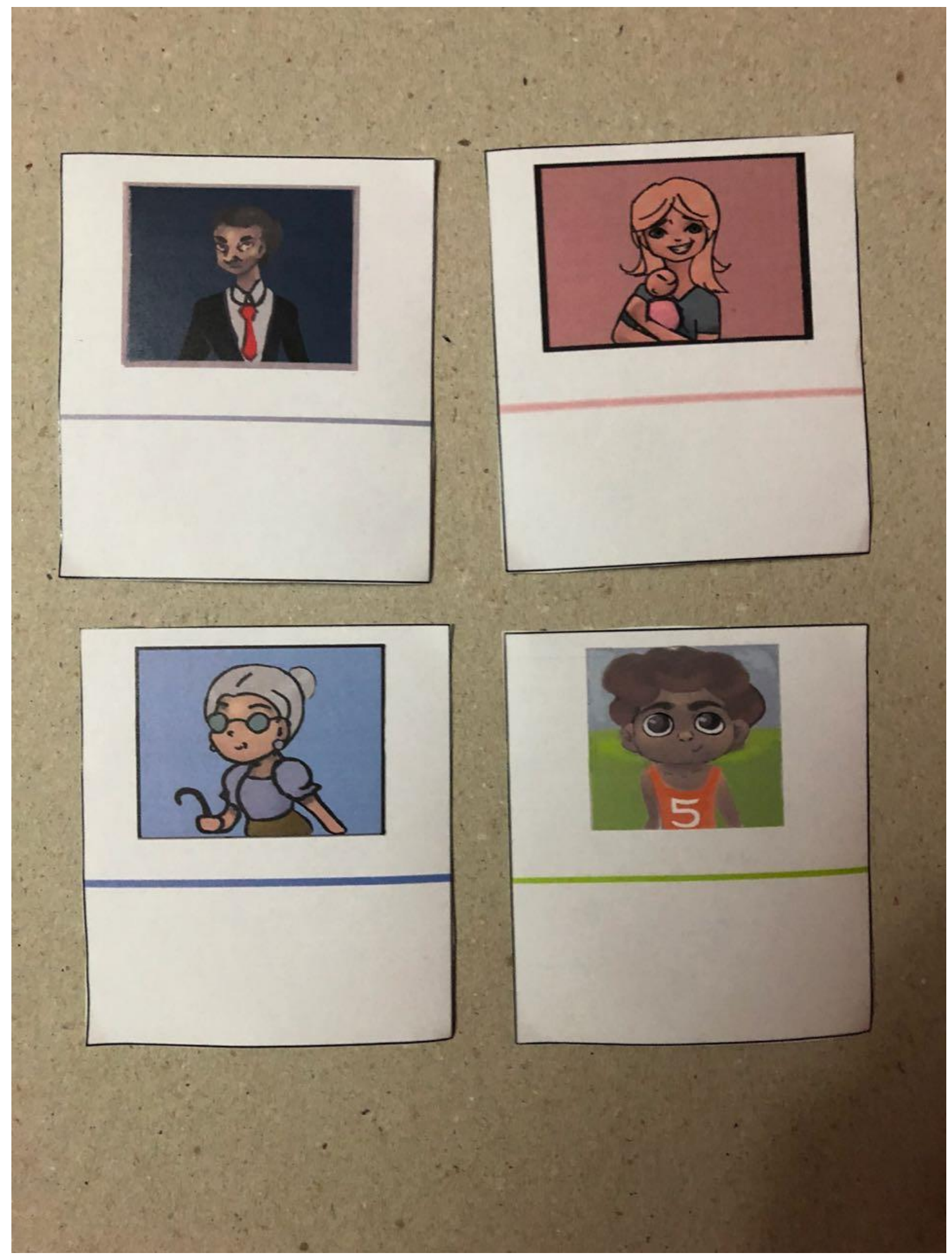

Figura 12: Cartas personagens. 


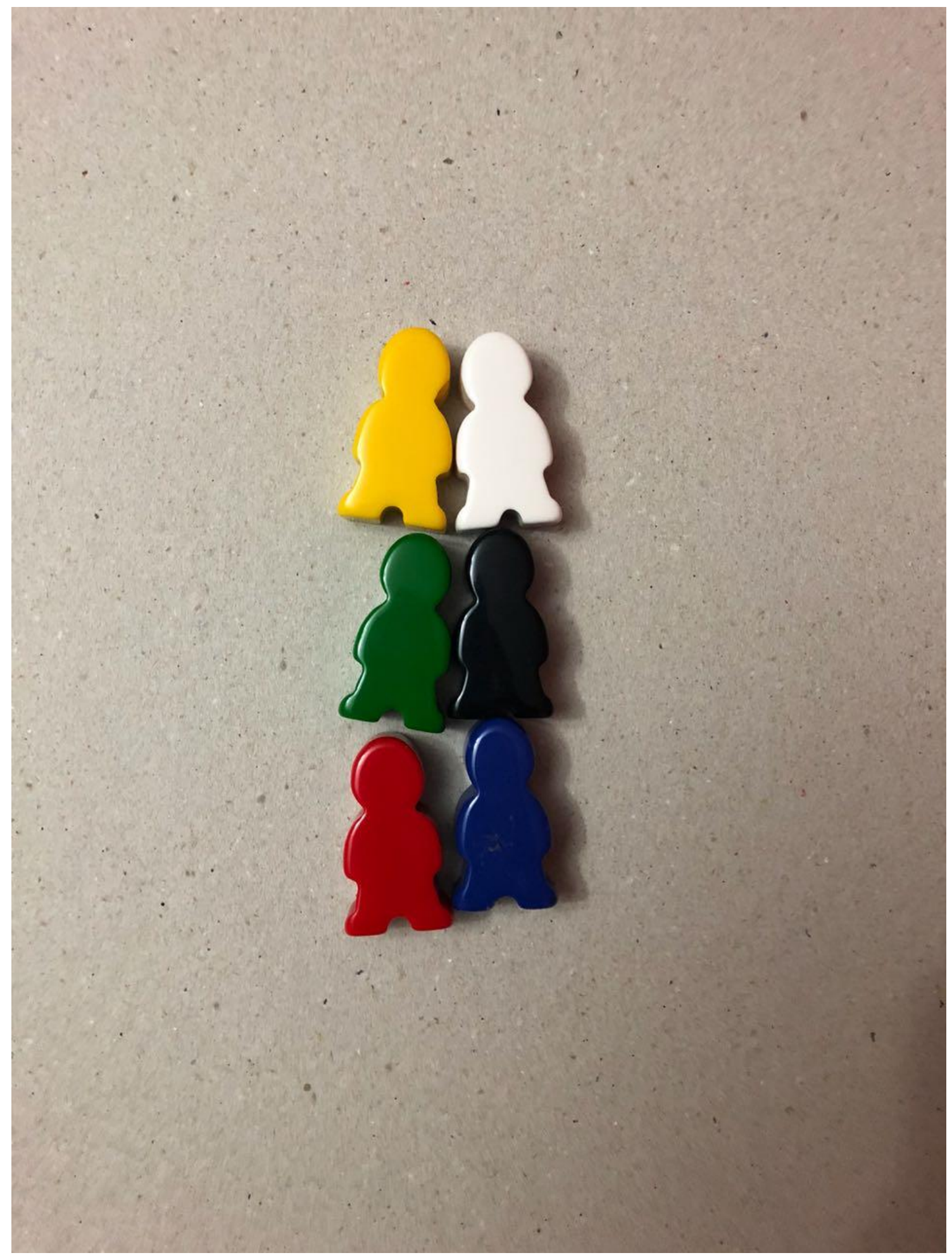

Figura 13: Peões de Jogo. 


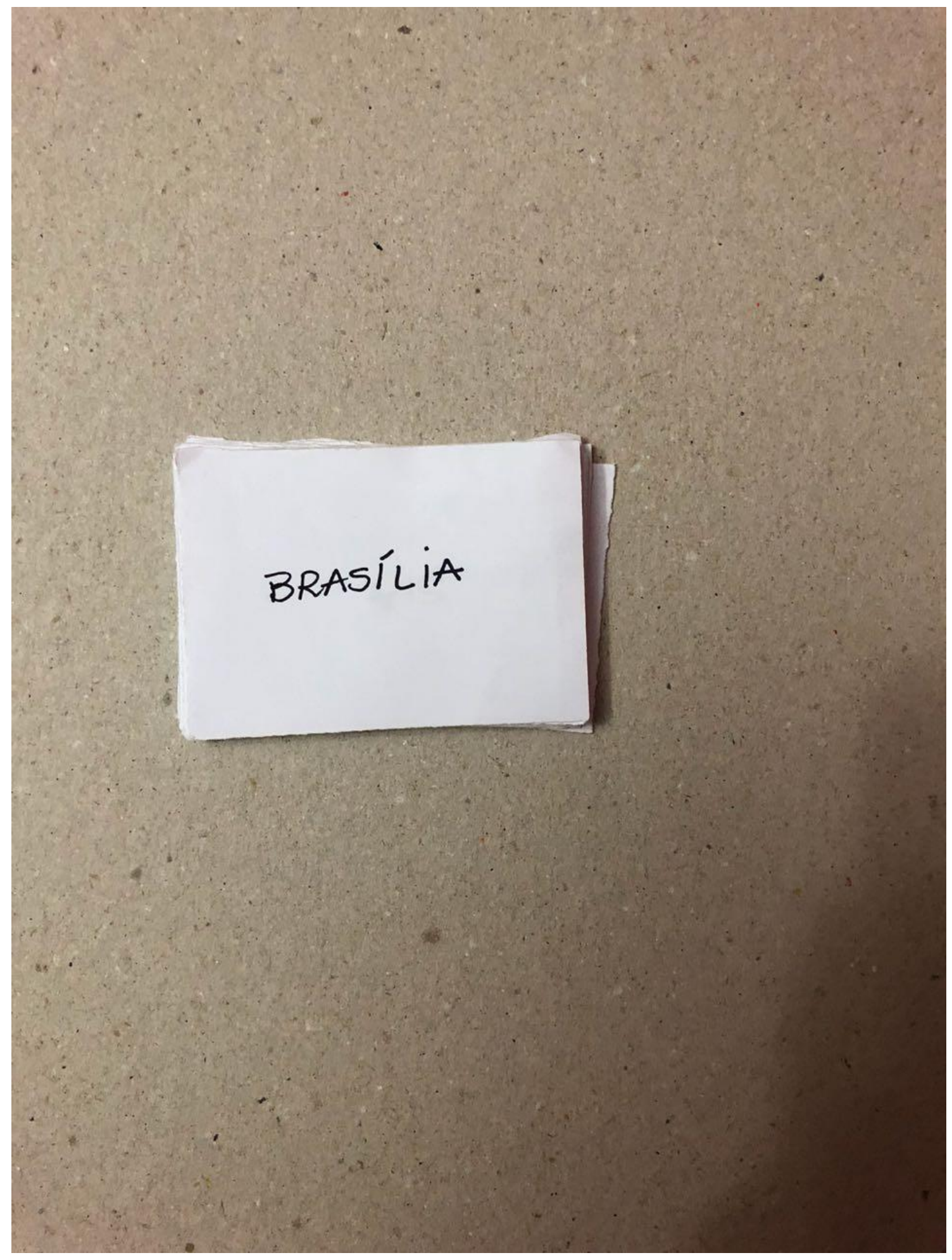

Figura 14: Cartas de partida e destino. 


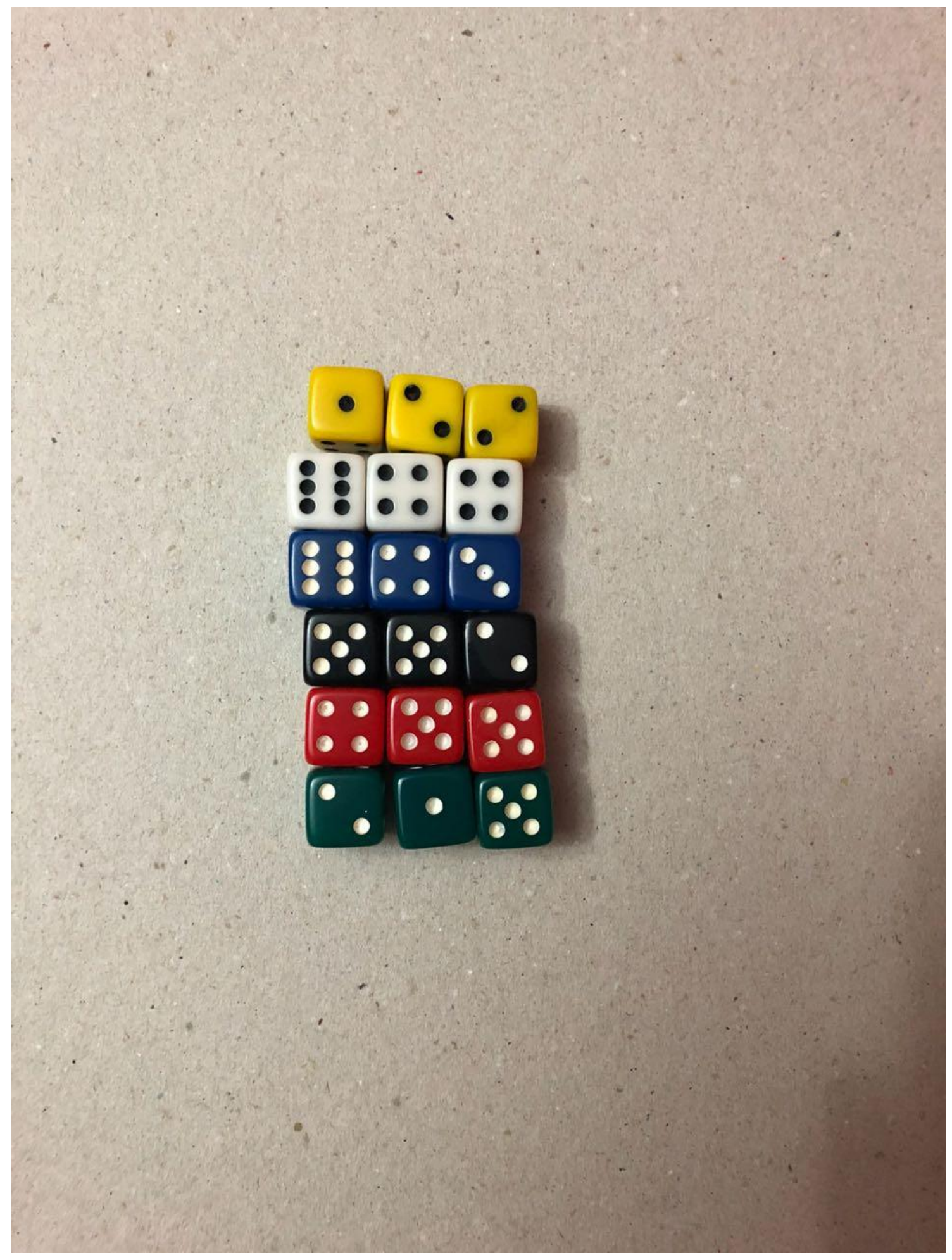

Figura 15: Dados de jogo. 


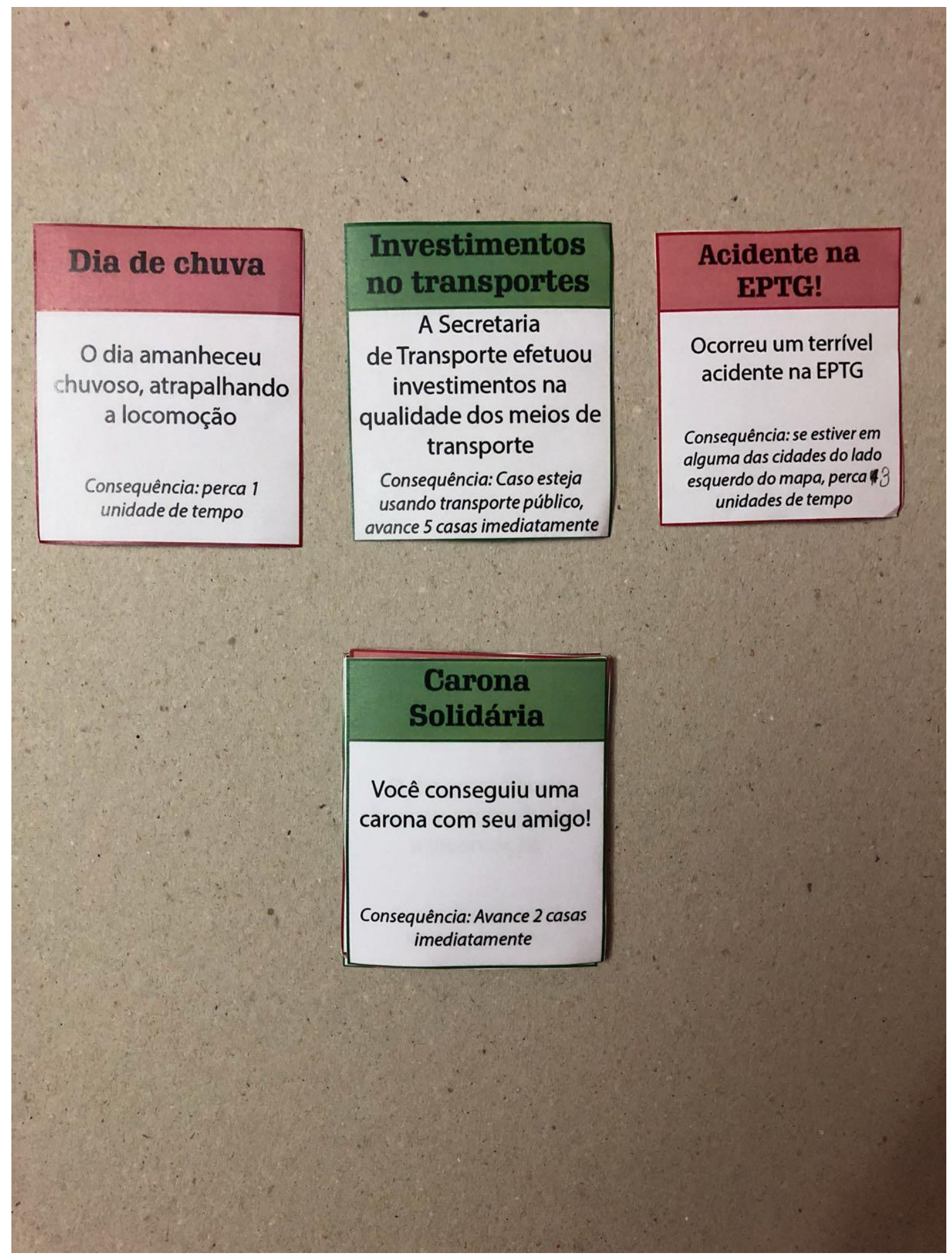

Figura 16: Cartas da cidade. 


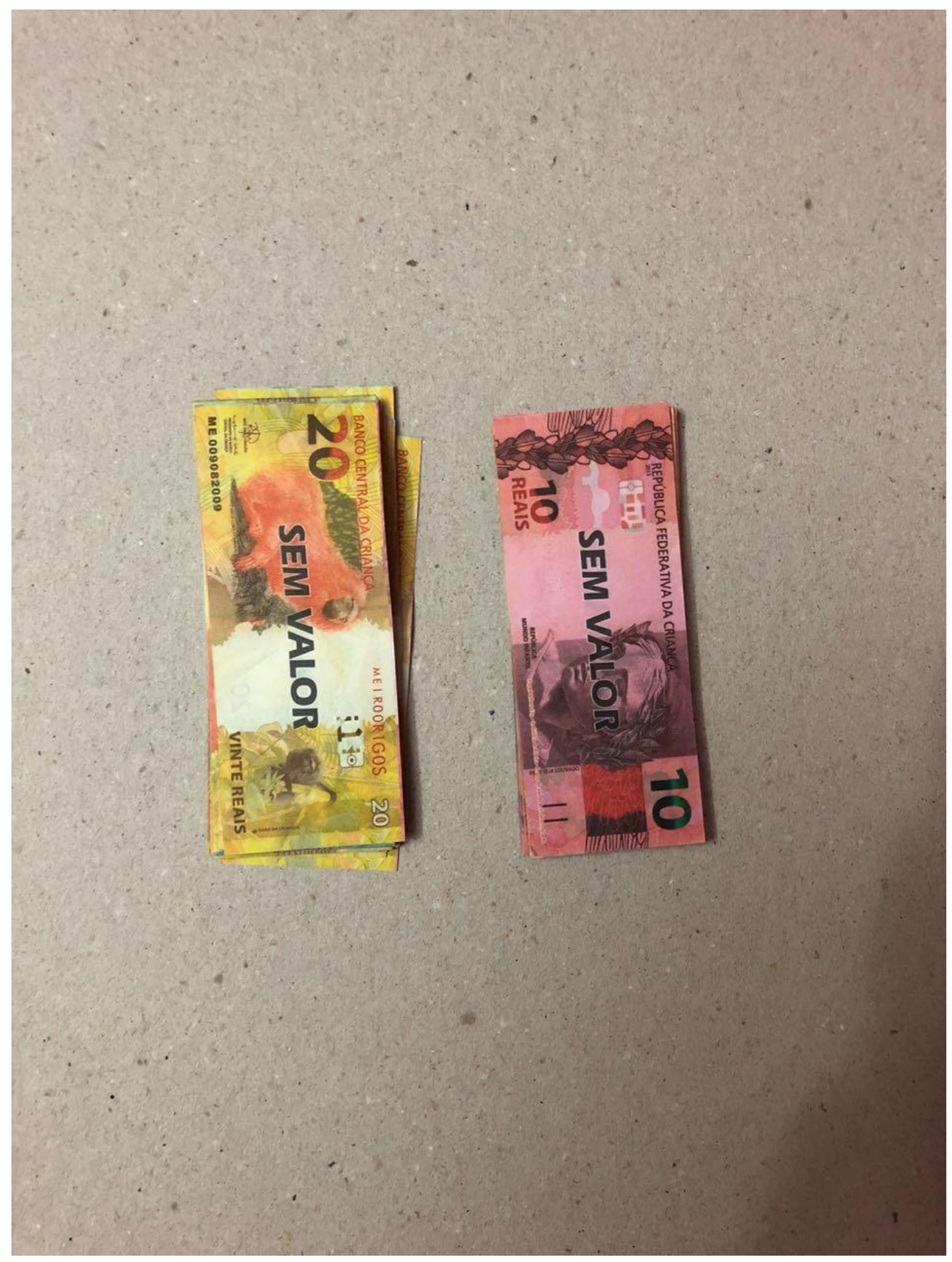

Figura 17: Dinheiro do jogo. 


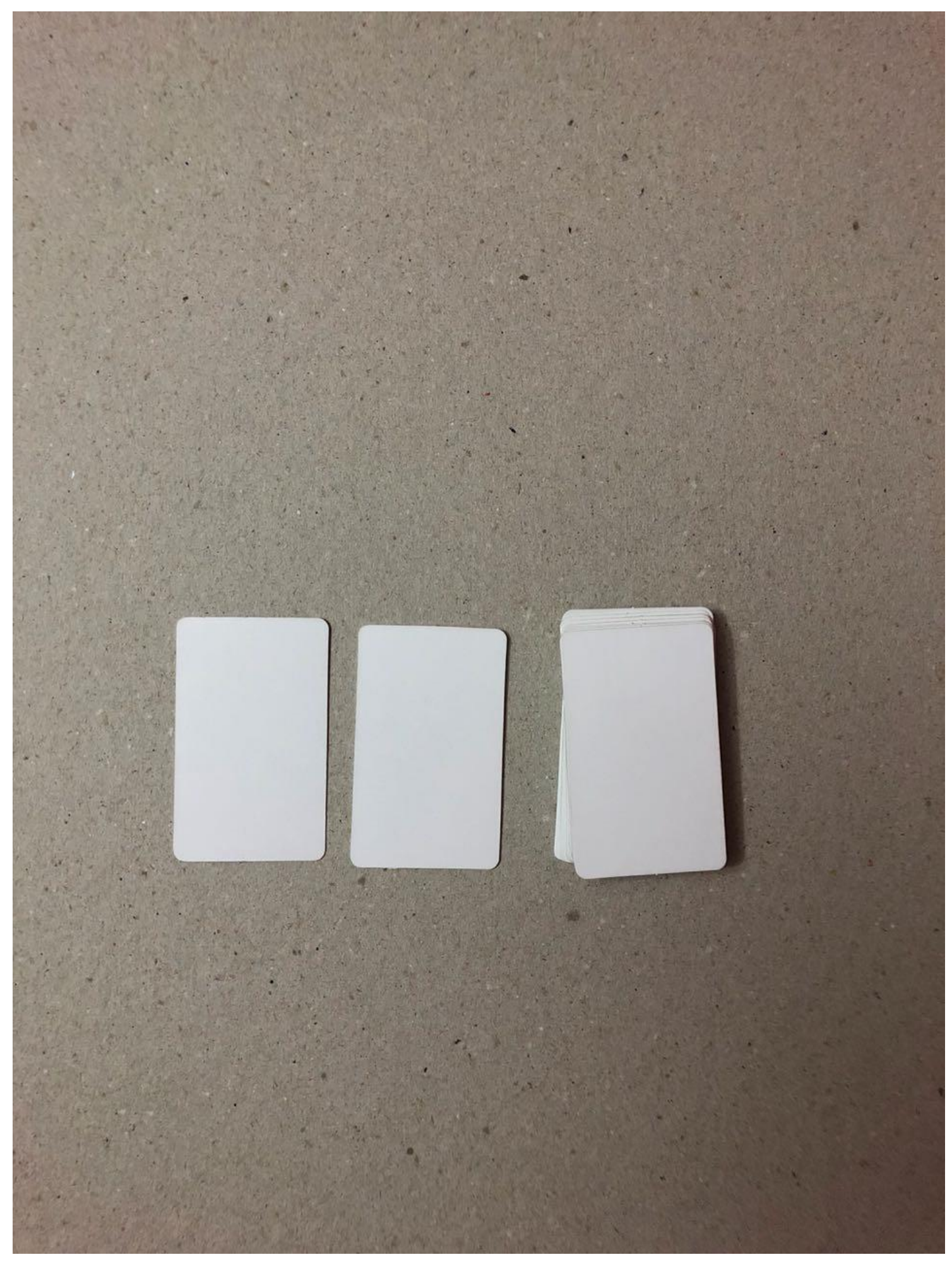

Figura 18: Cartas de pontuação. 